Geology and Stratigraphy of the Building 812 Area, Site 300, Lawrence Livermore National Laboratory

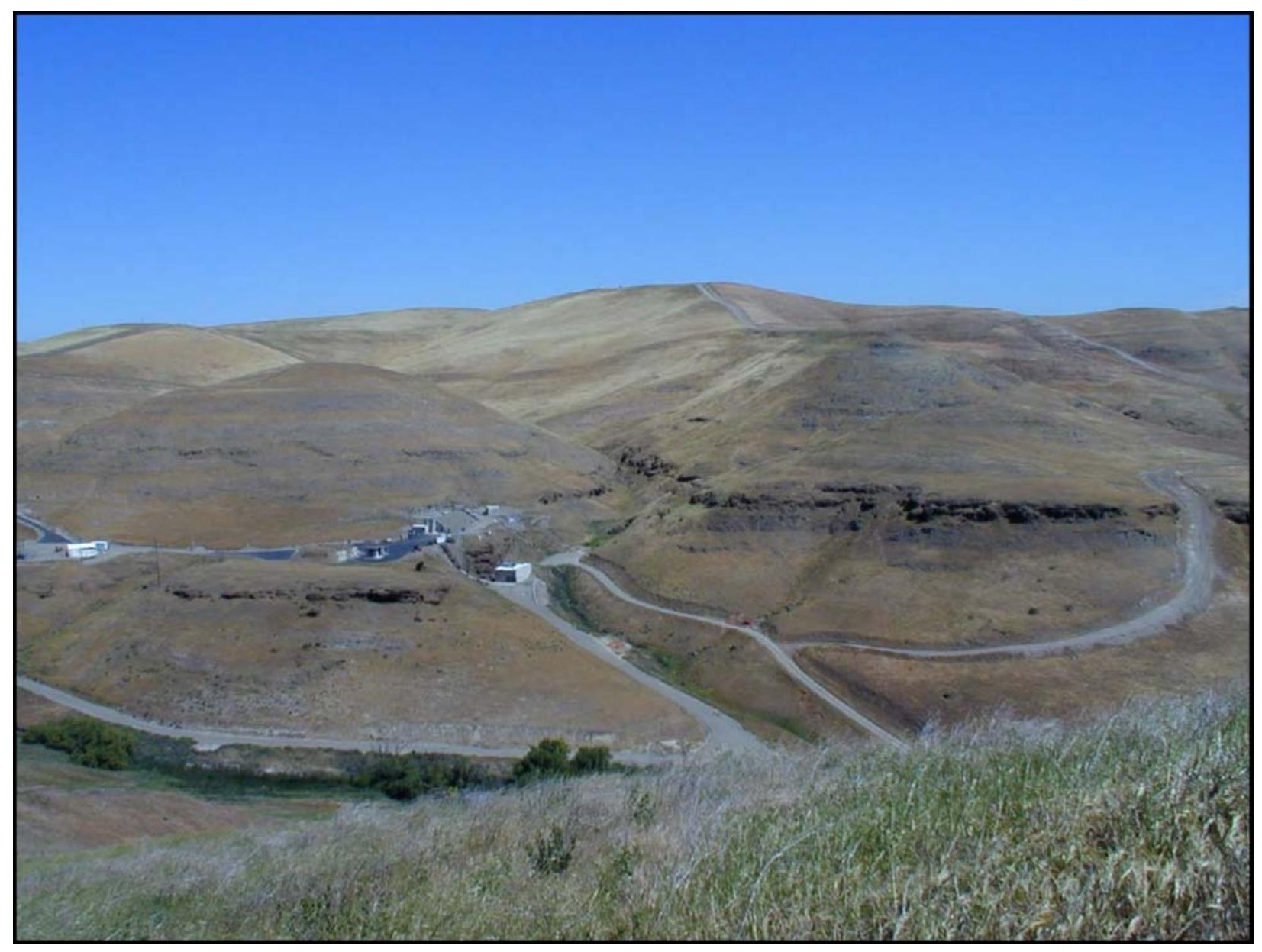

Kenneth D. Ehman, Ph. D., P.G. 6383

July 2005

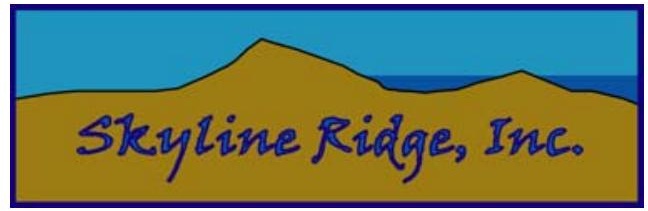

P. O. Box 150

Los Gatos, California 95031-0150 
This document was prepared as an account of work sponsored by an agency of the United States Government. Neither the United States Government nor the University of California nor any of their employees, makes any warranty, express or implied, or assumes any legal liability or responsibility for the accuracy, completeness, or usefulness of any information, apparatus, product, or process disclosed, or represents that its use would not infringe privately owned rights. Reference herein to any specific commercial product, process, or service by trade name, trademark, manufacturer, or otherwise, does not necessarily constitute or imply its endorsement, recommendation, or favoring by the United States Government or the University of California. The views and opinions of authors expressed herein do not necessarily state or reflect those of the United States Government or the University of California, and shall not be used for advertising or product endorsement purposes.

This work was performed under the auspices of the U.S. Department of Energy by University of California, Lawrence Livermore National Laboratory under Contract W-7405-Eng-48. 


\section{Geology and Stratigraphy of the Building 812 Area, Site 300, Lawrence Livermore National Laboratory}

\section{Table of Contents}

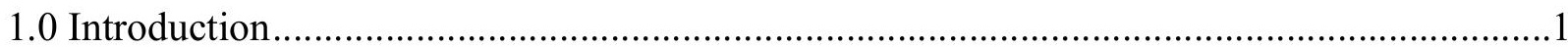

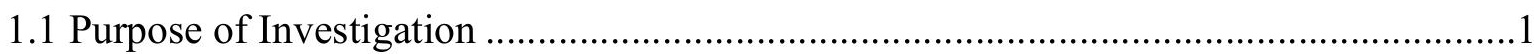

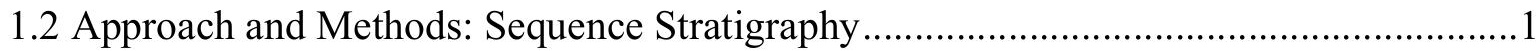

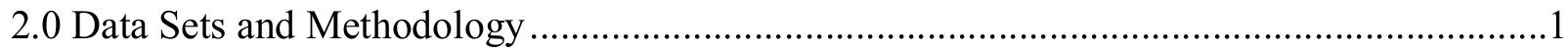

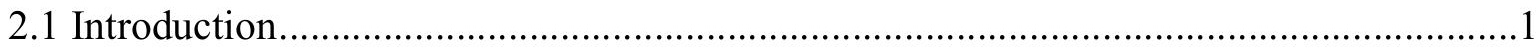

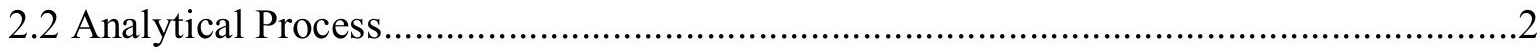

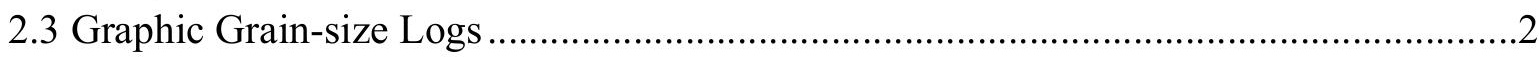

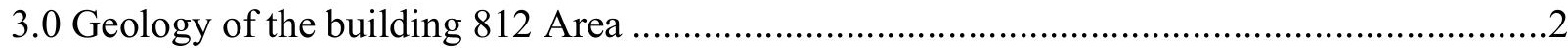

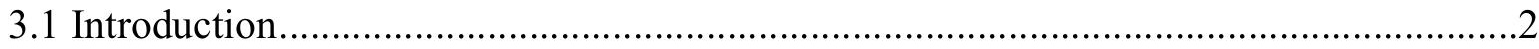

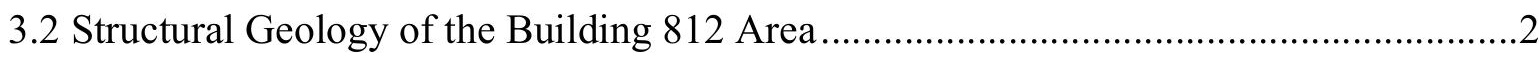

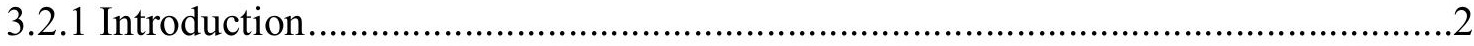

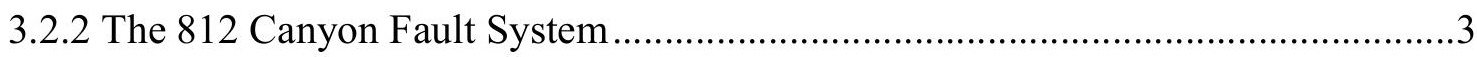

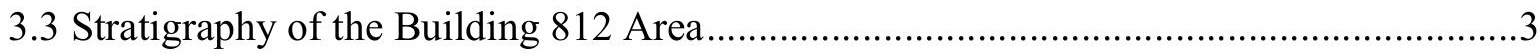

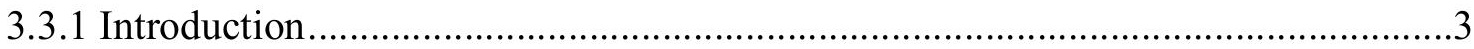

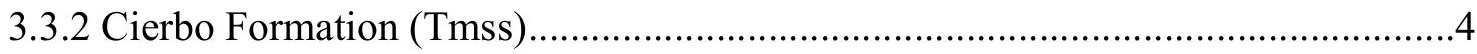

3.3.3 Contact between the Neroly and Cierbo Formations...........................................

3.3.4 Lower Claystone Unit, Neroly Formation $\left(\mathrm{Tnsc}_{0}\right)$............................................

3.3.5 Lower Blue Sandstone Unit, Neroly Formation $\left(\mathrm{Tnbs}_{0}\right)$........................................

3.3.6 Lower Conglomerate Unit, Neroly Formation (Tnbs 1 -cong) .................................6

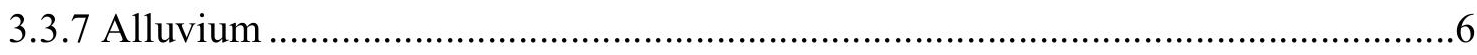

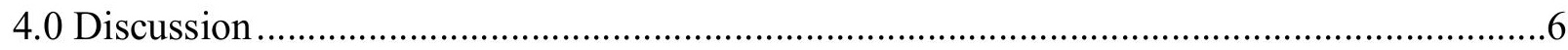

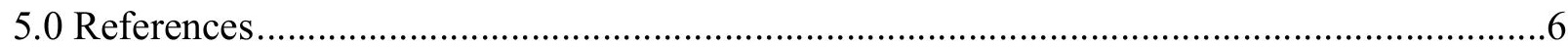

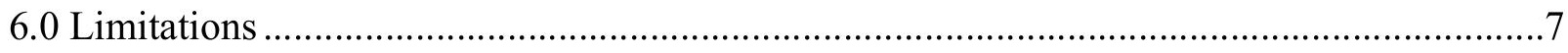

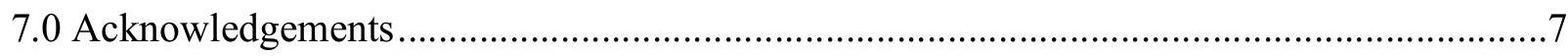

\section{List of Figures}

Figure 1 Location Map of Site 300, Lawrence Livermore National Laboratory.

Figure 2 Type stratigraphic log, Building 812 Area, W812-2009.

Figure 3 Graphic grain-size log from W-812-01 with explanation of lithology and sedimentary structures.

Figure 4 Geologic base map of the Building 812 Area.

Figure 5 Geologic cross sections A-A' and B-B', Building 812 Area

Figure 6 Photographic panorama of Building 812 Area showing geologic features.

Figure 7 Composite graphic grain-size logs correlation across fault 


\section{Appendices}

Appendix A Graphic grain-size logs for Building 812 Area

Appendix B Stratigraphic tops database, Building 812 Area 


\subsection{Introduction}

\subsection{Purpose}

The purpose of this project is to gain a better understanding of the stratigraphy and geologic structure of the Building 812 Area, Site 300 (Figure 1). This analysis is designed to help better delineate hydrostratigraphic units (HSUs) in order to enhance the understanding of the fate and transport of contaminants in the subsurface. The results of this investigation will assist Lawrence Livermore National Laboratory (LLNL) hydrogeologists to conduct work in a more focused and cost effective manner. This document is submitted to fulfill contract obligations for subcontract B530530.

\subsection{Approach and Methods: Sequence Stratigraphy}

Sequence stratigraphy is a method of describing the aquifers and aquitards in the subsurface that relates the depositional environment of the sediments to the stratigraphic framework in which they were deposited. Sequence stratigraphy provides a tool for predicting the lateral and vertical migration pathways of contaminants in the subsurface.

Sequence stratigraphy is the study of genetically related sedimentary facies within a framework of chronostratigraphically significant surfaces. A sequence is a relatively conformable, genetically related succession of strata bounded by unconformities. A sequence includes all genetically related lithologies (facies) between the defining unconformities (sequence boundaries) and may include regionally extensive aquifer and aquitard lithologies. A sequence boundary is a chronostratigraphic surface that can be correlated over a wide area. The identification of sequence boundaries is critical in defining the aquifer architecture of a basin.

A detailed discussion of the criteria for the recognition and correlation of sequence boundaries is found in Van Wagner and others (1990). In the analysis done for the Building 812, the focus was in the physical stratigraphic correlation between the different boreholes and their tie to surface outcrops.

\subsection{Data Sets and Methodology}

\subsection{Introduction}

A variety of data sets have been integrated to build the geologic model at Building 812 . Sequence stratigraphy provides a means to integrate these data sets into a conceptual geologic model. Data sets available include:

- Lithologic descriptions from boreholes.

- Preserved continuous core.

- Geophysical log suite from boreholes.

- Optical televiewer logs (OPTV logs) from boreholes.

- Geologic mapping.

- High-resolution aerial photography. 
- Photographic panoramas of the 812 Area.

\subsection{Analytical Process}

The process of the investigation has been:

- The review and compilation of well files.

- Construction of graphic grain-size logs from core descriptions

- Examination of core from three key wells: W-812-1924; W-812-1929; W-812-2009

- Examination of outcrop geology in Building 812 area

- Review of OPTV logs from the boreholes of the Building 812 area

- Review and modification of geologic map of the area (Carpenter and others, 1990)

- Construction of datumed stratigraphic and structural cross sections integrating graphic grain-size logs, e-logs, core descriptions, and outcrop geology.

\subsection{Graphic Grain-size Logs}

Graphic grain-size logs were constructed for all the wells in the Building 812 area and are presented in Appendix A. Figure 2 is the graphic grain-size log for W-812-2009 illustrating the Building 812 area stratigraphy. This $\log$ is considered the type stratigraphic section for the Building 812 area since in the deepest borehole drilled (287 feet below ground surface [bgs]) and penetrates the greatest stratigraphic thickness. Figure 3 is a graphic grain-size log from W-81201 with an explanation of lithology and sedimentary structures.

Geophysical logs, if available, are plotted on either side of the lithologic column. The gamma ray log is plotted on the left side of the lithology column, and the resistivity log is plotted on the right. Well construction details (sand pack and screened intervals) are shown on the left side of the lithologic column (Figure 3).

\subsection{Geology of the Building 812 Area}

\subsection{Introduction}

The surface geology of the Building 812 Area was mapped by Carpenter and others (1990) at a scale of 1.0 inch $=200$ feet and was modified in this report and presented on Figure 4 . Two cross sections were constructed and are shown on Figure 5. Figure 6 is a photographic panorama of the Building 812 Area showing the distribution of the outcrops and geographic features in the area.

\subsection{Structural Geology of the Building 812 Area}

\subsubsection{Introduction}

The Building 812 Area is underlain by the lower part of the Miocene-aged Neroly Formation $\left(\operatorname{Tnbs}_{1}\right.$ and $\left.\mathrm{Tnbs}_{0}\right)$. The stratigraphy has a very shallow dip (less than 5 degrees) to the northeast (Carpenter and others, 1990) (Figures 4 and 6). The shallowly dipping Miocene stratigraphy is 
dissected by two major drainages that contain thin alluvial sediments. The 812 canyon is present on the east side of the Building 812 complex. This canyon intersects Elk Ravine south of the complex area.

One of the most notable features in the area is a fault that trends north by northeast, observed on the northwest side of 812 canyon and is designated here as the "812 Canyon Fault (A)" (Figures 4, 5 and 6). Another subparallel fault, here designated the "812 Canyon Fault (B)" is also present in the canyon inferred from subsurface data. Both of these faults are discussed below.

\subsubsection{The 812 Canyon Fault System}

Figure 6 is a photograph of the 812 canyon looking north. Well-exposed conglomerates of the lower $\operatorname{Tnbs}_{1}$ dip gently northeast and are present on both sides of the fault with apparent down to the north offset. The well-pronounced fault scarp of the 812 Canyon Fault (A) is observed in the field and on the high-resolution aerial photograph (Figures 4 and 6). The measured orientation and dip of the fault trace on the northwest side of Building 812-E is 209 degrees, vertical dip, with slickenslide lineations that dip 7 degrees south. The apparent offset is down to the northwest, and Carpenter and others (1990) show the fault as a series of en echelon left-lateral splays approximately 1,200 feet up the canyon to the northeast of the Building 812 area. There appear to by at least 4 different fault splays that can be observed on aerial photos. To the south, the fault extends at least to Elk Ravine. The main part of Spring 6 appears to correspond to the location where the 812 Canyon Fault crosses Elk Ravine. West of Elk Ravine, the trace of the fault is unclear, but geomorphic evidence suggests that the 812 Canyon Fault may actually offset the Elk Ravine Fault. The Elk Ravine Fault trends northwest - southeast along Elk Ravine and extends north toward the Building 865 area (Figures 4 and 6).

The 812 Canyon Fault (B) isolates wells W-812-1925 and W-812-1933 (see Cross section A-A', Figure 5). The 812 Canyon Fault (B) appears to have more vertical offset on it than the 812 Canyon Fault (A) as shown on Figure 5. Total apparent vertical offset of the fault system can be determined by evaluation of the cross sections shown on Figure 5 and comparing the stratigraphy encountered in W-812-1924 (southeast fault block) and in W-812-1929 (northwest fault block) (Figure 7). The total amount of apparent vertical offset is 50 to 60 feet.

\subsection{Stratigraphy of the Building 812 Area}

\subsubsection{Introduction}

The Miocene-aged stratigraphy of the Building 812 area is divided into two broad stratigraphic units, the lower Neroly Formation and the underlying Cierbo Formation. Figure 2 is a summary of the stratigraphy encountered in the subsurface in Building 812 Area. The oldest stratigraphy encountered in the Building 812 Area is composed of the sandstones and claystones of the Cierbo Formation (Tmss). Overlying the Cierbo Formation, the basal Neroly Formation is divided into a claystone/siltstone dominated unit $\left(\mathrm{Tnsc}_{0}\right)$ and is in turn overlain by an interbedded blue sandstone and claystone/siltstone unit $\left(\mathrm{Tnbs}_{0}\right)$. The interval is capped by the lower conglomerate of the Neroly Formation (Tnbs ${ }_{1}$-cong). Thin recent-aged alluvial channel material (Qal on Figure 4) is present in Elk Ravine and in 812 Canyon on the east side of the Building 812 Area. The following is a discussion of each unit and subunit present in the Building 812 Area. 


\subsubsection{Cierbo Formation (Tmss)}

The Cierbo Formation (Tmss) was encountered in four borings in the Building 812 Area: W812-04, W-812-1922, W-812-1924, and W-812-2009 (Figures 2, 4, and 5), and is not present in outcrop. The unit is distinguished by the presence of light gray friable quartzose sandstones, as opposed to the blue-gray volcanic-rich sandstones of the overlying Neroly Formation. Although the mapping of Carpenter and others (1990) shows the presence of Cierbo Formation in the Elk Ravine area of the Building 812 region, a redefinition of the unit in this report assigns those exposures to the lower part of the Tnsc ${ }_{0}$ unit, and the thus the Tmss does not crop out at the surface in the study area.

The sandstone within the Cierbo Formation is characterized by fine- to medium-grained, light gray to light olive gray sandstone that is finely laminated, and shows both cross beds and ripple laminations. Some of the laminations are thin organic-rich layers (coaly material). In core from W-812-2009, the sandstone appears to be burrowed and bioturbated, and no laminations are present. Rock fragments and feldspar grains are also present in the sandstones. Because the sand is very friable, recovery tends to be fair to poor through the interval. The sand unit thickness ranges from 5 feet (W-812-1922) to approximately 36 feet (W-812-04). Correlations shown on Figure 5 suggest that the Cierbo Formation sandstones are laterally discontinuous, and probably channelized suggested by the local occurrence of a gravelly sandstone at the base of one of the sandstone beds (W-812-04).

Finer-grained lithologies are observed within the Cierbo Formation in W-812-1924 and W-8122009, where quartzose sandstone of is overlain by dark greenish-gray clayey siltstone, silty claystone, sandy siltstone, and silty sandstone. The clayey siltstone and silty claystone are fractured and typically have a sheared appearance in core, and is difficult to distinguish from similar lithologies in $\mathrm{Tnsc}_{0}$. Possible burrows were observed in the silty claystone in W-8121924.

Three wells, W-812-1929, W-812-1922, and W-812-1924 are screened within the Cierbo Formation sandstone (Figure 7).

\subsubsection{Contact between the Neroly and Cierbo Formations}

In previous Site 300 geologic reports, the top of the Cierbo Formation has been recognized by the first occurrence of quartzose sandstone in contrast with the overlying volcanic-clastic Neroly sandstones. The quartzose sandstones of the Cierbo Formation appear to be channelized and discontinuous, thus the contact between the formations is not a continuous correlative surface that can be easily mapped. This investigation reevaluated this contact and redefined the contact based on the stratigraphy in the Building 812 Area. In the Building 812 Area, the contact between the units is subtle, and has been typically overlooked during the onsite core description. The contact was recognized after detailed examination of core from W812-1924 and W-8122009. In core from W-812-2009, the surface is present at 227 feet bgs and is marked by a thin gravel lag with pebbles up to $50 \mathrm{~mm}$ in diameter and a possible large mudstone rip up clast overlain by a thin silty medium- to coarse- grained sandstone with inclined laminations defined by charcoal material (Figure 2). The basal unit is marked by a distinctive geophysical log character in both W-812-1924 and W-812-2009 (Figure 5). This surface was used as the contact 
(sequence boundary) between the formations because it appeared to be a laterally correlative stratigraphic surface. Elsewhere at Site 300, there appears to be a discrete, slightly discordant unconformity between the Cierbo and overlying Neroly Formations. Future investigations in different areas of Site 300 will provide more insights into this important stratigraphic surface.

\subsubsection{Lower Claystone Unit in Neroly Formation $\left(\operatorname{Tnsc}_{0}\right)$}

The lower claystone unit in the Neroly Formation $\left(\mathrm{Tnsc}_{0}\right)$ rests unconformably above mudstones and sandstones of the Cierbo Formation (Figures 2 and 5) and below the sandstones and silty sandstones of the $\operatorname{Tnbs}_{0}$. The unit is dominated by dark greenish-gray claystone, siltstone, clayey siltstone and silty claystone with thin, discontinuous silty sandstones and sandy siltstones and is approximately 140 feet thick. The bedding features within the finer-grained lithologies are homogenized by rooting and show some evidence of bioturbation. The clayey siltstones and silty claystones are fractured and typically have a sheared appearance in core.

The $\mathrm{Tnsc}_{0}$ is divided into two informal members, $\mathrm{Tnsc}_{0}$-lower and $\mathrm{Tnsc}_{0}$-upper that are divided by a dark greenish-gray fine- to coarse sandstone that present across the 812 area and designated Tnsc $_{0}$-upper-B (Figure 2 and 5). The Tnsc ${ }_{0}$-upper-B ranges from in thickness from about 7 to 15 feet.

Most of the wells on the east side of the 812 Canyon Fault are screened within sandstones within the $\mathrm{Tnsc}_{0}$. With the exception of the $\mathrm{Tnsc}_{0}$-upper-B, none of the sandstones within the $\mathrm{Tnsc}_{0}$ in the Building 812 area appear to be correlative. Five wells are screened in the Tnsc $\mathrm{C}_{0}$-upper-B (see Figure 7). The rest are screened in other sandstone units within the $\operatorname{Tnsc}_{0}$.

\subsubsection{Lower Blue Sandstone Unit, Neroly Formation $\left(\operatorname{Tnbs}_{0}\right)$}

The lower blue sandstone unit in the Neroly Formation $\left(\operatorname{Tnbs}_{0}\right)$ rests unconformably above mudstones, siltstones, and sandstones of the $\operatorname{Tnsc}_{0}$ and unconformably below the conglomerate of the Tnbs 1 -cong (Figures 2 and 5). The Tnbs 0 is exposed in outcrop on the east side of the 812 Canyon Fault, and thus is not penetrated by any wells in the east fault block (Figures 4 and 6). The exception is in W-812-1925 and W-812-1933 where there is a thin section of $\mathrm{Tnbs}_{0}$ preserved within a fault slice of the 812 Canyon Fault system (Figure 5). A thin section of Tnbs 0 may be present at the very top of W-812-1926 and W-812-1931 (Figure 5). The Tnbs 0 is present in the subsurface on the west side of the 812 Canyon Fault system and is penetrated by four wells, W-812-01, W-812-02, W-812-1929, and W-812-2009 and is approximately 50 feet thick.

There are three sandstone subunits within the $\operatorname{Tnbs}_{0}: \operatorname{Tnbs}_{0}-\mathrm{A}, \operatorname{Tnbs}_{0}-\mathrm{B}$, and $\operatorname{Tnbs}_{0}-\mathrm{C}$ (Figure 2 and 5). Thin siltstones and claystones separate the three subunits. $\mathrm{Tnbs}_{0}-\mathrm{C}$ rests unconformably on the $\operatorname{Tnsc}_{0}$ and is a dark grayish brown to dark bluish gray fine- to medium- sandstone that is parallel laminated and approximately 12 to 18 feet thick. The overlying Tnbs $_{0}-\mathrm{B}$ is similar but is thinner than the underlying $\operatorname{Tnbs}_{0}-\mathrm{C}$, ranging in thickness from 2 to $10 \mathrm{feet}$. It is also more interstratified with thin finer-grained siltstones and claystones. $\mathrm{Tnbs}_{0}-\mathrm{C}$ is a dark grayish brown fine- to medium- grained sandstone that shows trough cross stratification and rip up clasts. Tnbs $_{0}-\mathrm{C}$ appears to be the main water-bearing unit on the west side of the 812 Canyon Fault. Wells W-812-01, W-812-02, and W-812-1929 are screened in the $\mathrm{Tnbs}_{0}-\mathrm{C}$, and well W-8122009 is screened in the $\mathrm{Tnbs}_{0^{-}} \mathrm{B}$ (Figure 7). No wells are currently screened in the $\mathrm{Tnbs}_{0}-\mathrm{A}$. 


\subsubsection{Lower Conglomerate Unit, Neroly Formation, ( $\operatorname{Tnbs}_{1}$-cong)}

The lower conglomerate unit of the Neroly Formation (Tnbs 1 -cong) is well exposed in the Building 812 Area on both sides of the 812 Canyon Fault (Figure 6). The resistant ledgeforming outcrops are one of the most distinctive aspects of the geology in the Building 812 area

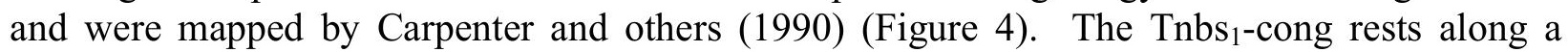
sharp, erosive contact above the Tnbs0. The unit is composed of pebble- to cobble- clast supported conglomerate with interstratified sandstone and gravelly sandstone. Clasts are dominantly volcanic in origin. The unit is between 30 to 50 feet thick. Four wells penetrate the Tnbs $_{1}$-cong, W-812-01, W-812-02, W-812-1929, and W-812-2009, all located on the west side of the 812 Canyon Fault. The Tnbs 1 -cong is unsaturated, and no wells are screened in the unit in the Building 812 area.

\subsubsection{Alluvium}

Thin alluvial deposits and weathered bedrock are present in 812 Canyon and in Elk Ravine. Alluvial materials include sand, silt, silty sand, sandy clay, and gravelly silt and gravelly sand. The thickest alluvial deposits in 812 Canyon are on the order of $10 \mathrm{feet}$, and this may include weathered bedrock. Elk Ravine contains a greater thickness of alluvial material, at least 24 feet is present at NC2-22 and N2-23. Three wells are screened in the alluvium/weathered bedrock interval: NC2-23, W-812-08, and W-812-1921.

\subsection{Discussion}

The definition and delination of the stratigraphy and structure of the Building 812 Area is the first step in the hydrostratigraphic analysis of the groundwater system in the area. Based on this analysis, a stratigraphic tops database has been established (Appendix B). Working with LLNL hydrogeologists, a 3-dimensional EarthVision hydrogeologic model will be generated by integrating the surface and subsurface data. It appears that both stratigraphy and structure (particularly the 812 Canyon Faults) play important roles in the aquifer architecture of the area.

\subsection{References}

Carpenter, D. W., Dugan, W.R., Matiek, R. S. and Taffet, M. J., 1990, Preliminary Geologic Map of Section 22 (T3N, R4W), Lawrence Livermore National Laboratory Site 300 (unpublished)

Van Wagoner, J. C., Mitchum, R. M., Campion, K. M., and Rahmanian, V. D., 1990. Siliciclastic sequence stratigraphy in well logs, cores, and outcrops: American Association of Petroleum Geologists Methods in Exploration Series, No. 7, 55 p. 


\subsection{Limitations}

This report and evaluation presented herein have been prepared in accordance with generally accepted professional standard and is based solely on the scope of work and services described herein. This document has been prepared solely for the use of Lawrence Livermore National Laboratory. Any use of this report, in whole or in part, by a third party for other than the purposes noted herein is at such party's sole risk.

\subsection{Acknowledgements}

The author would like to thank Vic Madrid and Michael Taffet of the Environmental Restoration Division of Lawrence Livermore Laboratory for their technical contributions to this work. Rob Davis and Zafer Demir helped by providing data for this analysis. Kim Heyward provided graphic support. 


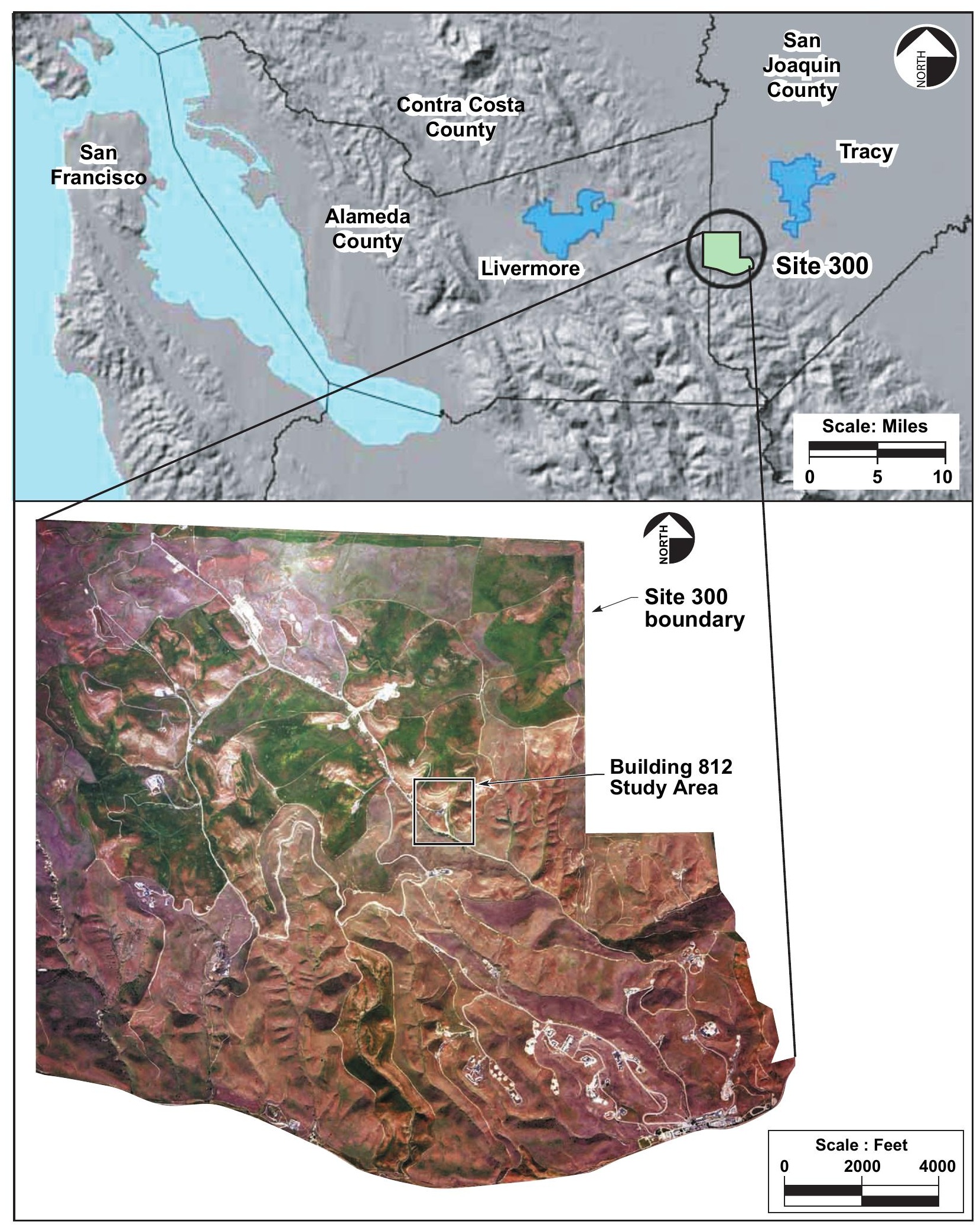

Figure 1. Location Map of Site 300, Lawrence Livermore National Laboratory 


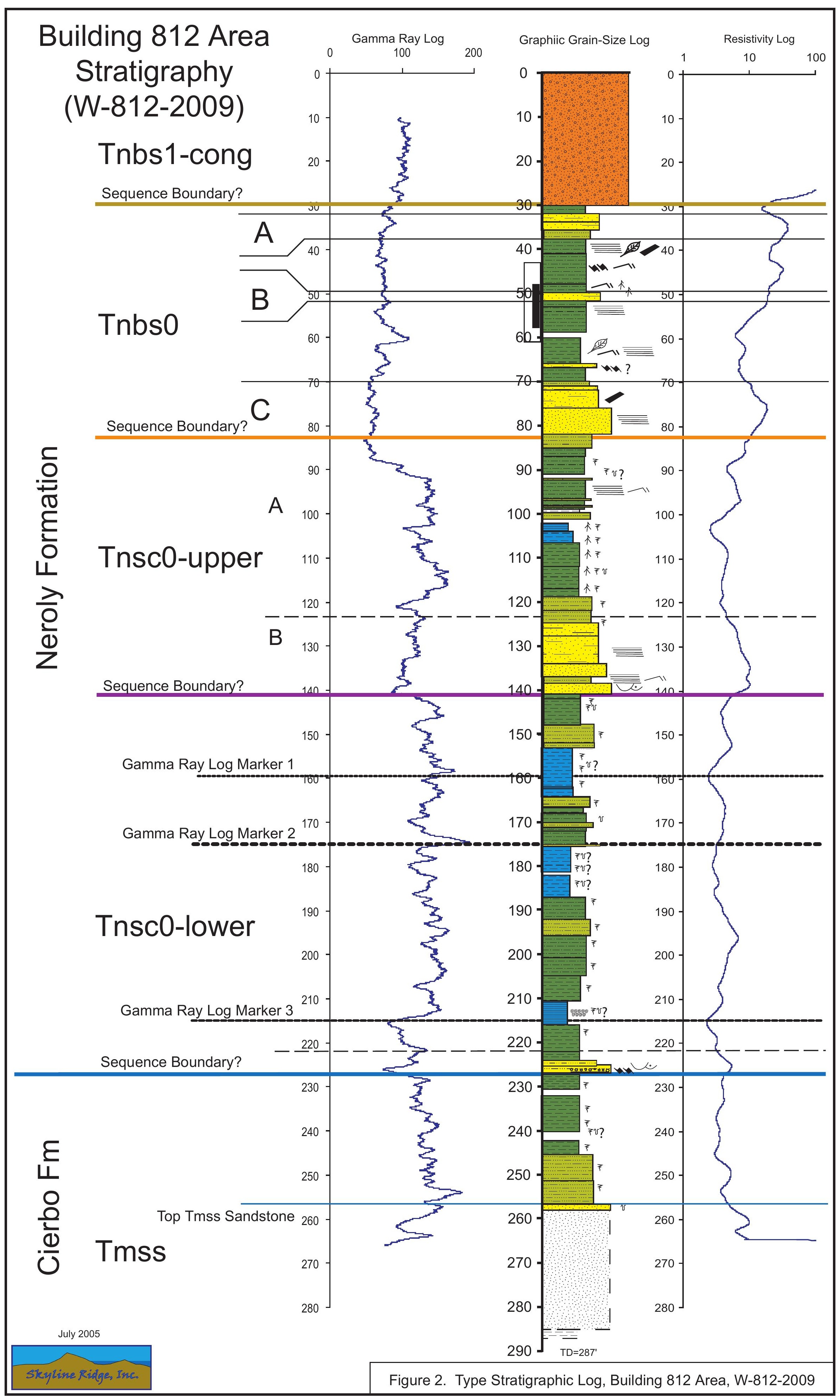




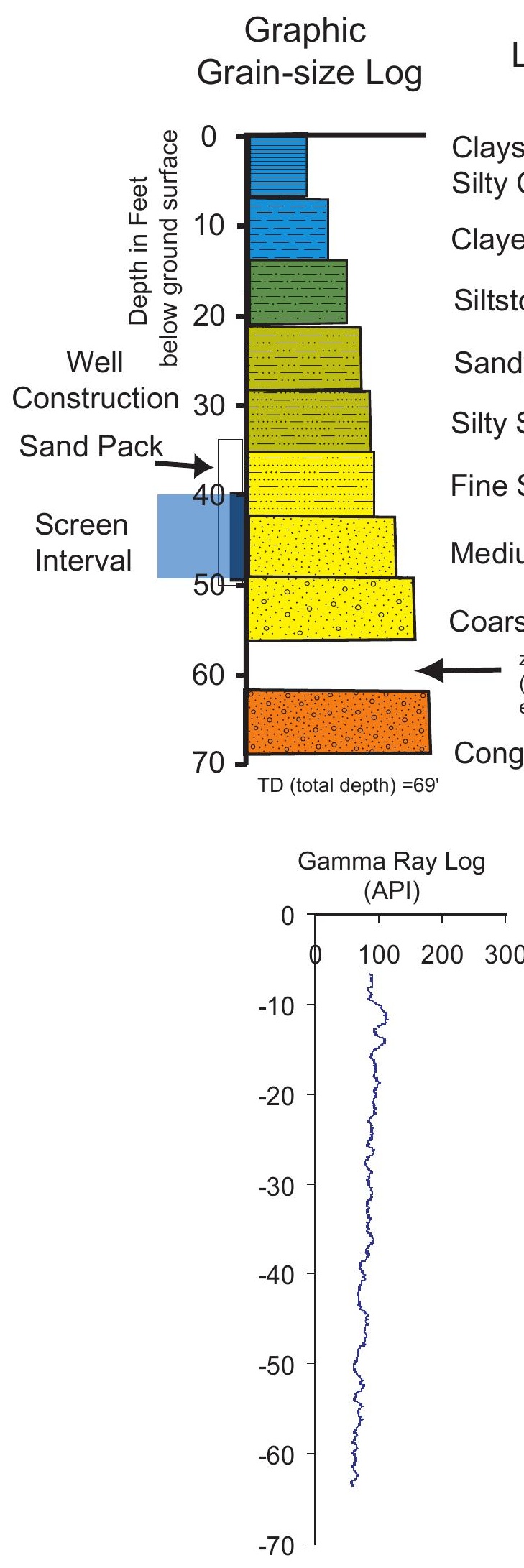

Lithology

Sedimentary structures and features from core examination

$\begin{aligned} & \text { planar } \\ & \text { laminations } \\ & \text { trough cross beds } \\ & \text { burrows } \\ & \text { coaly plant material }\end{aligned}$
root casts
rip-up clast
clay drape
current ripple
churned bedding
leaf imprint

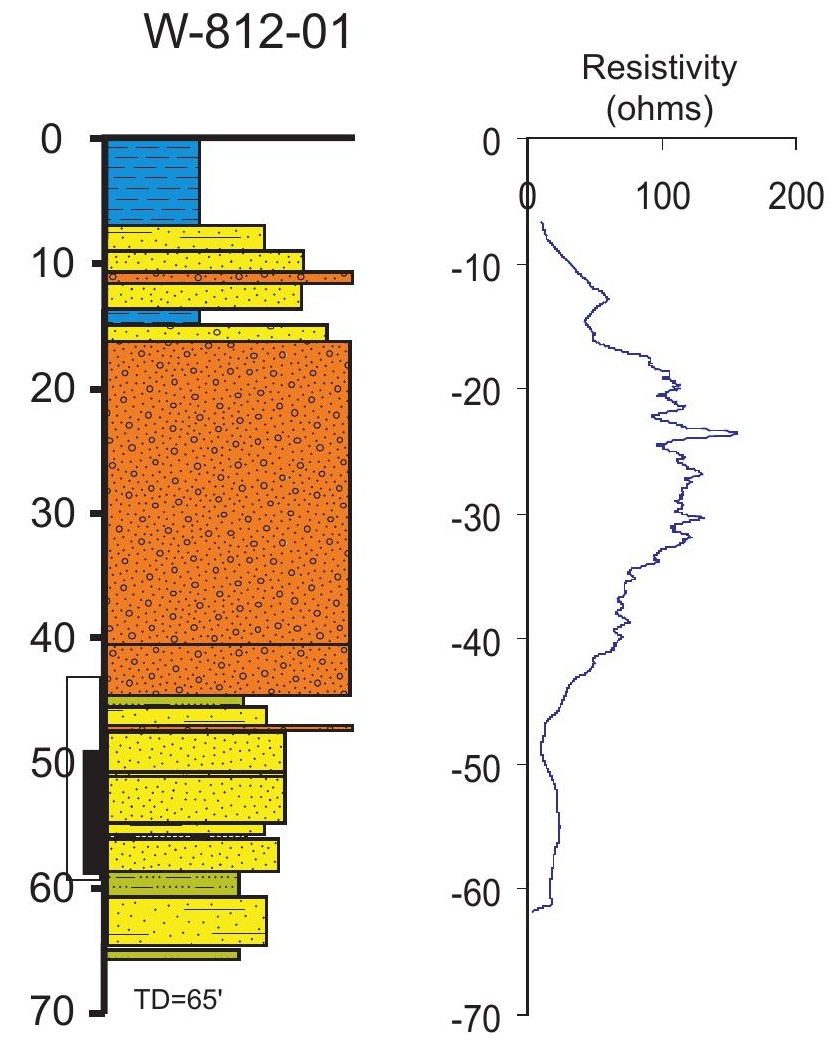

Figure 3. Graphic grain-size log from W-812-01 with explanation of lithology and sedimentary structures. 


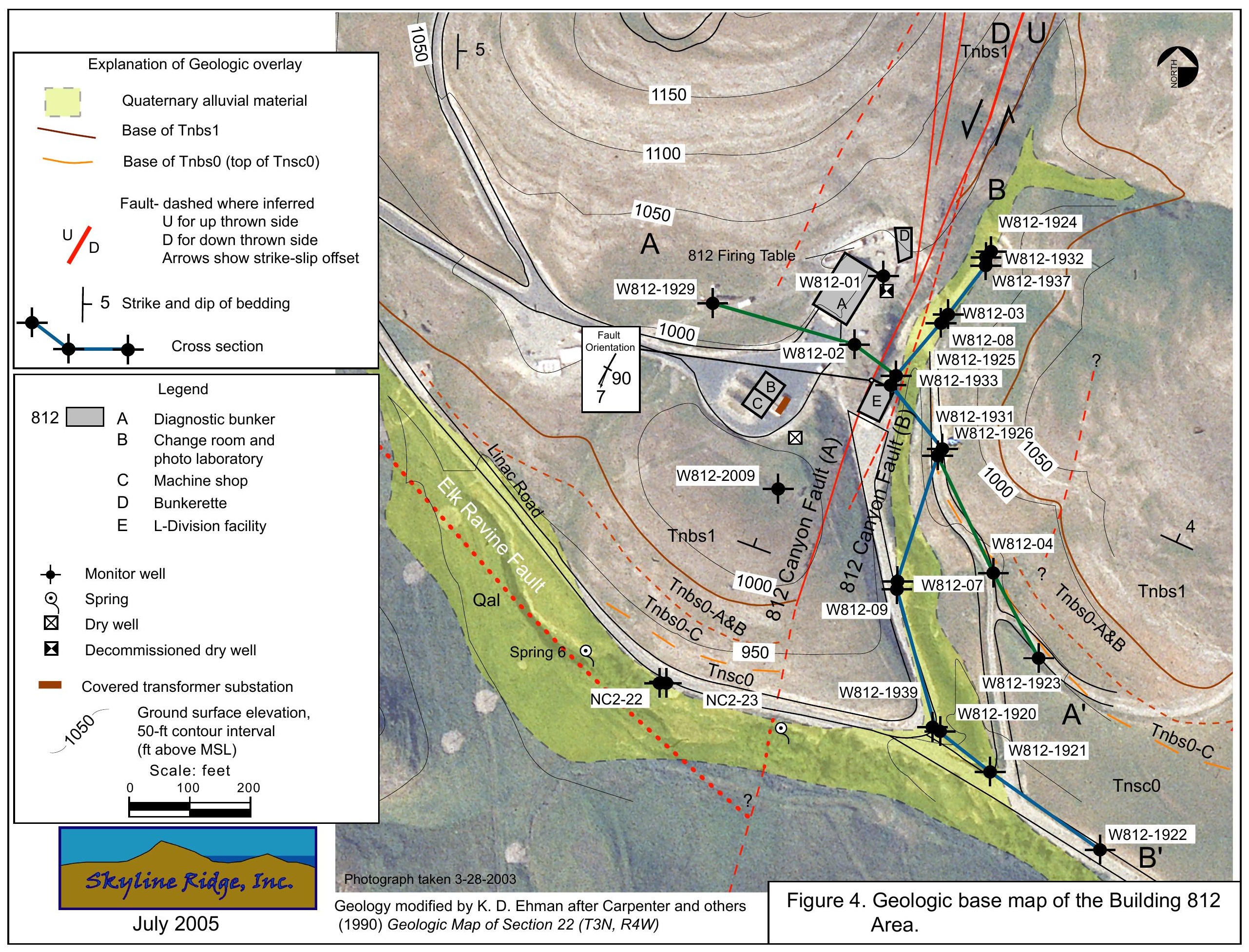



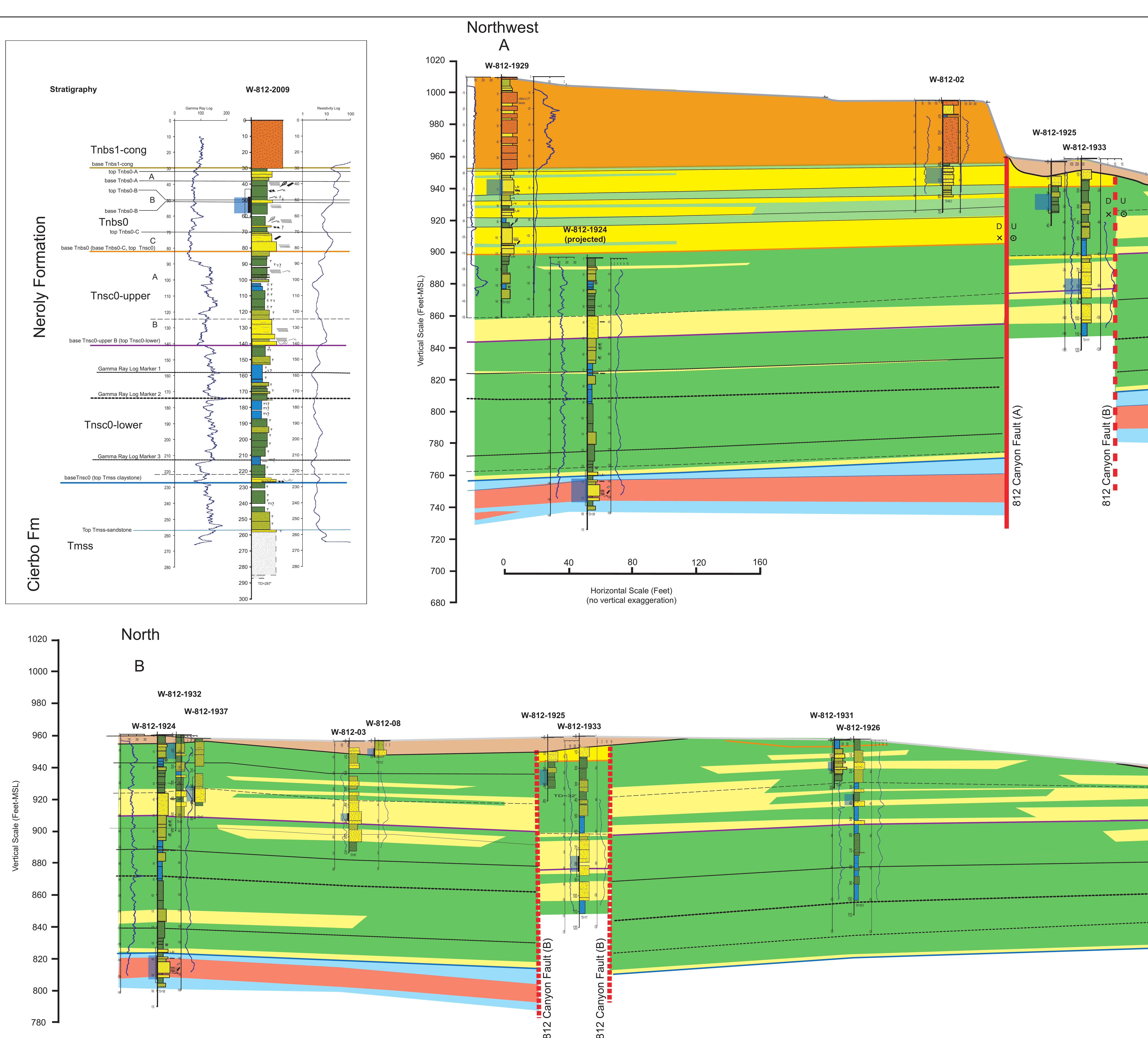

North

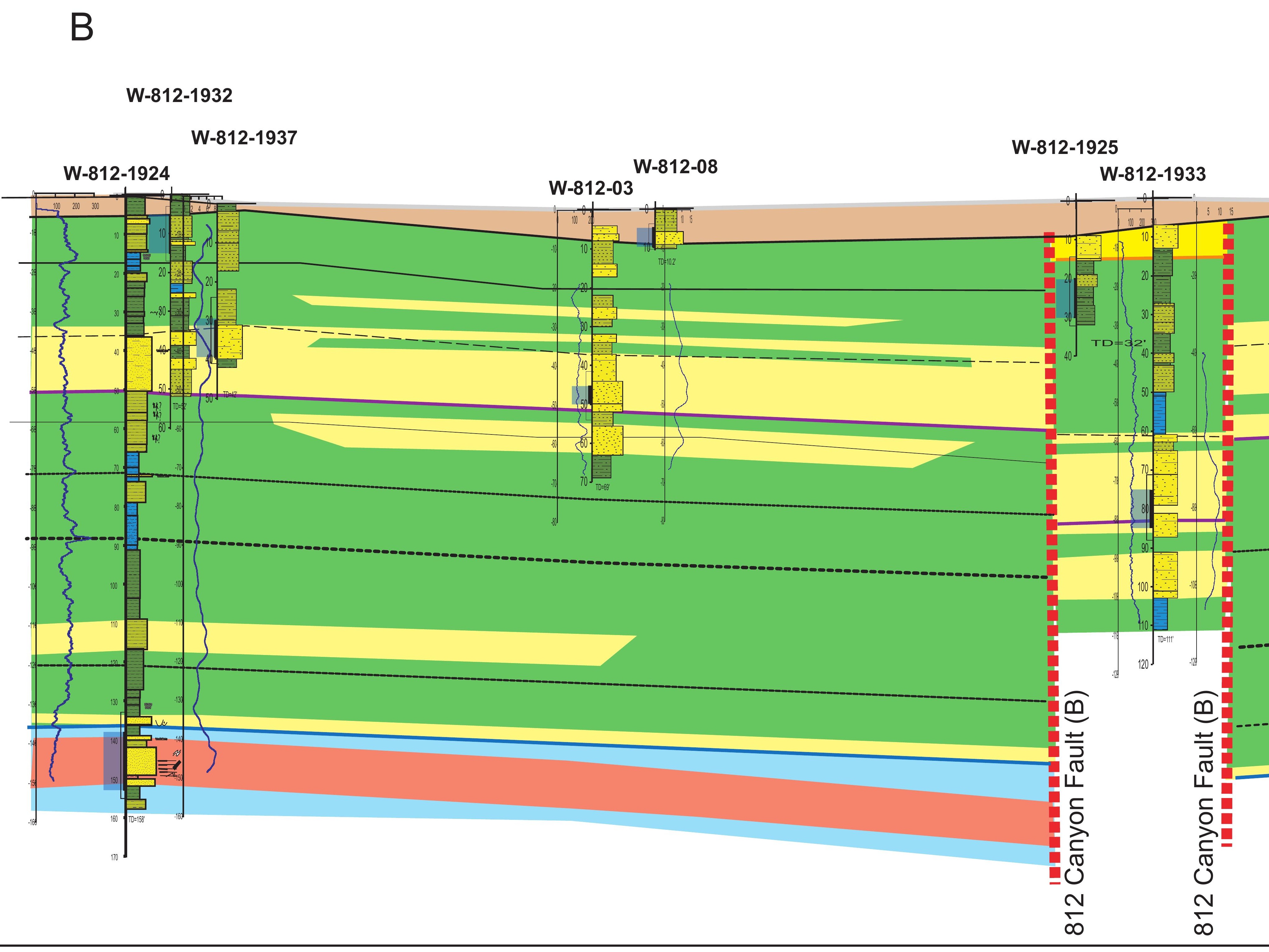

w.821-1931.
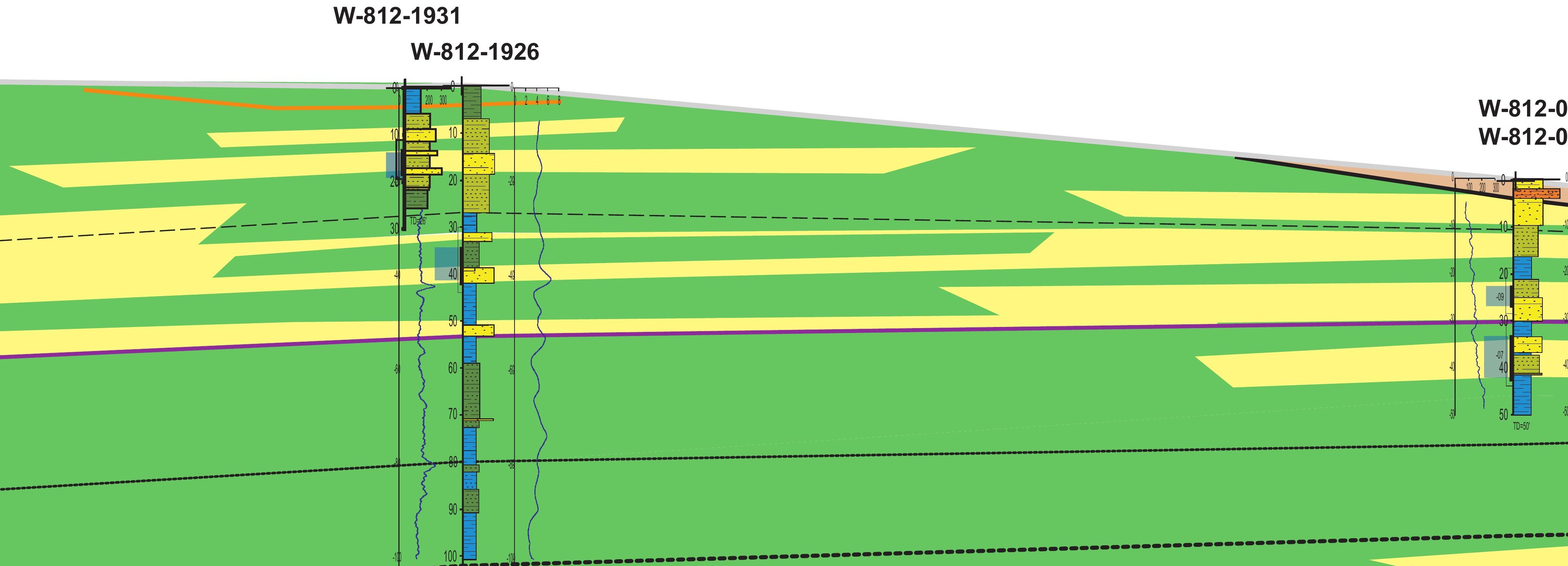

.

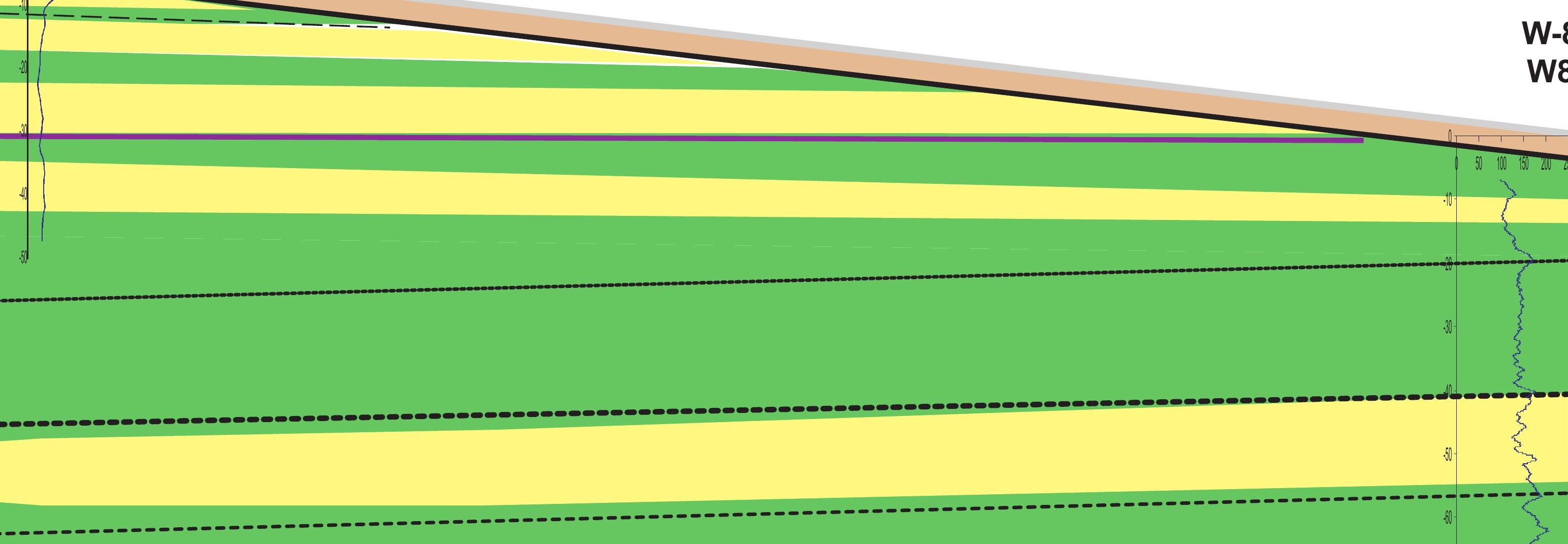

\section{Explanation}

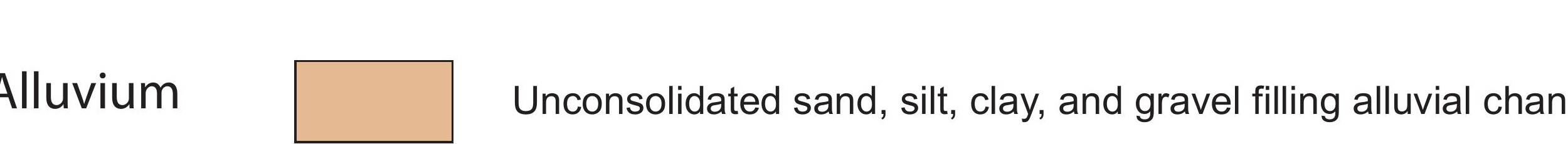

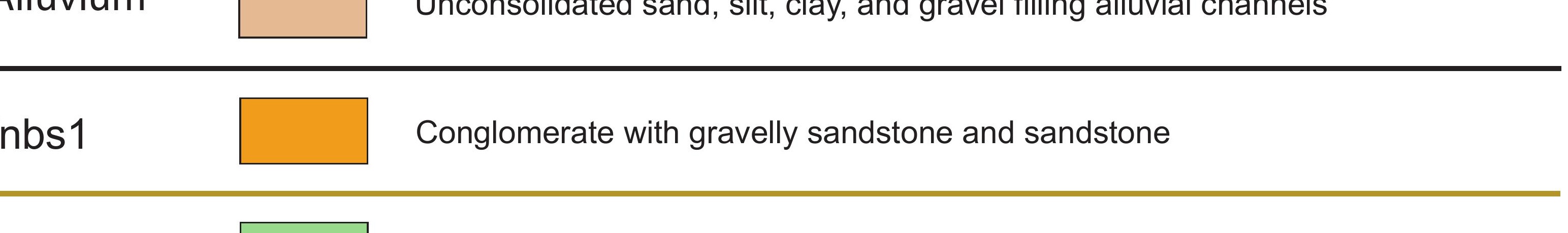

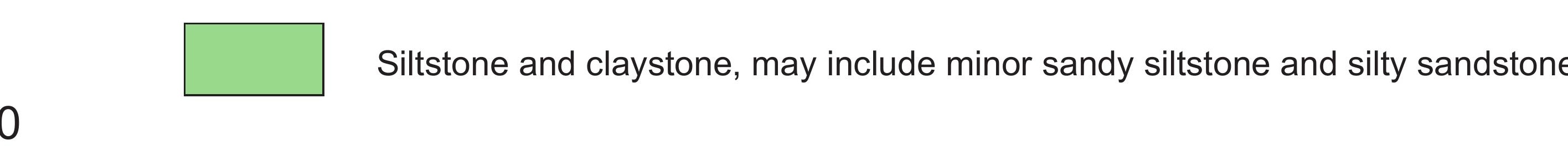

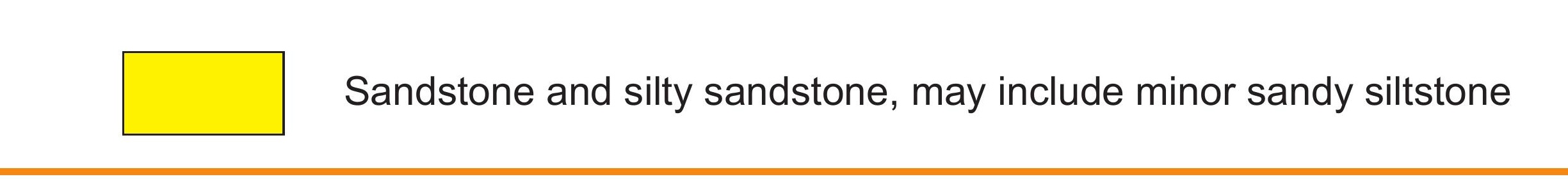

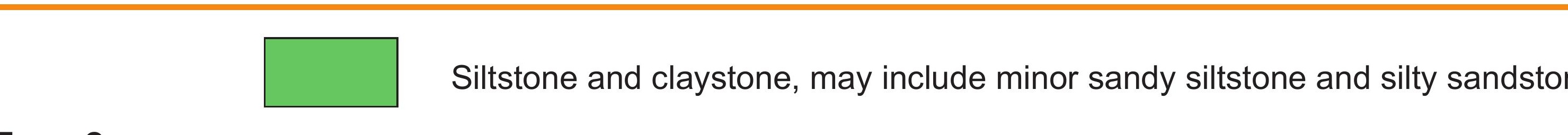

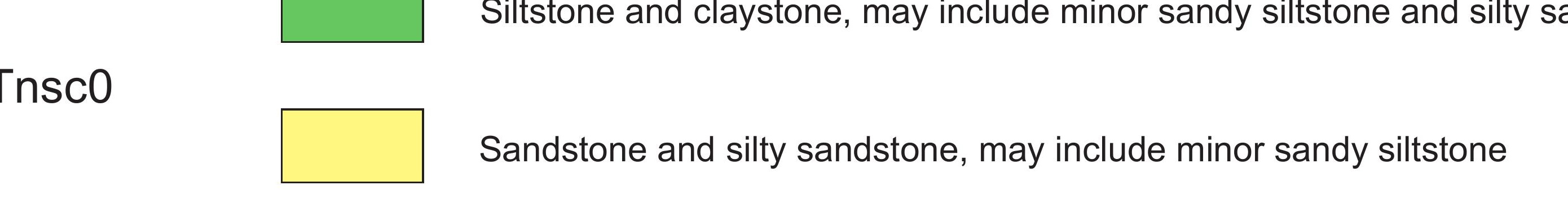

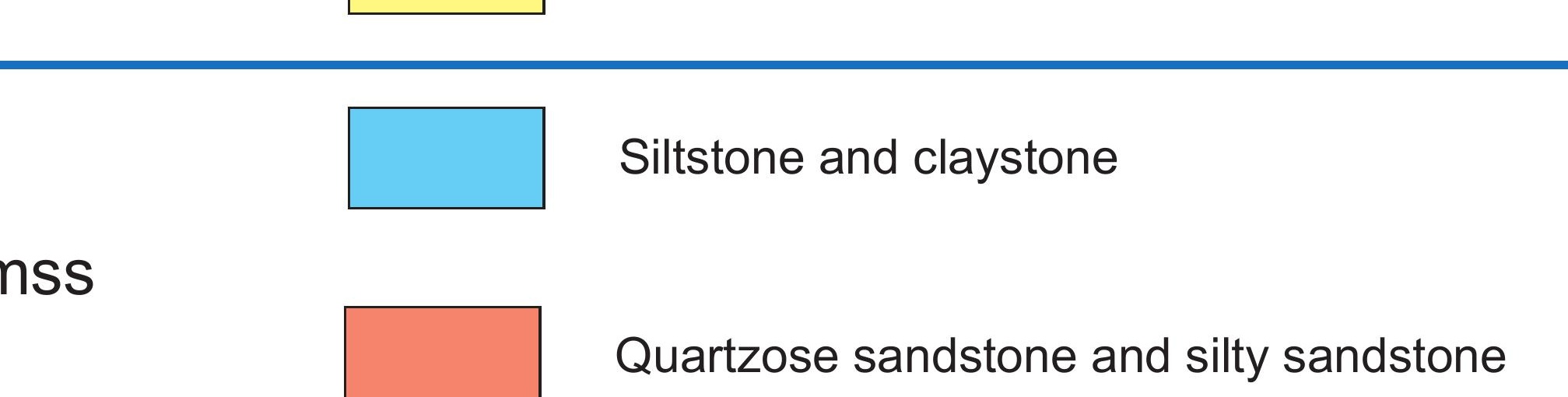

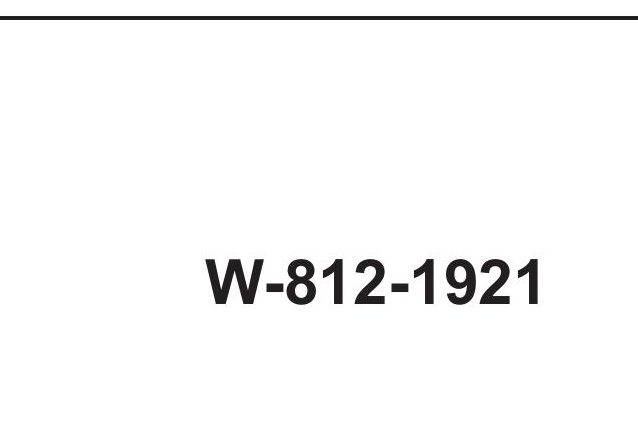




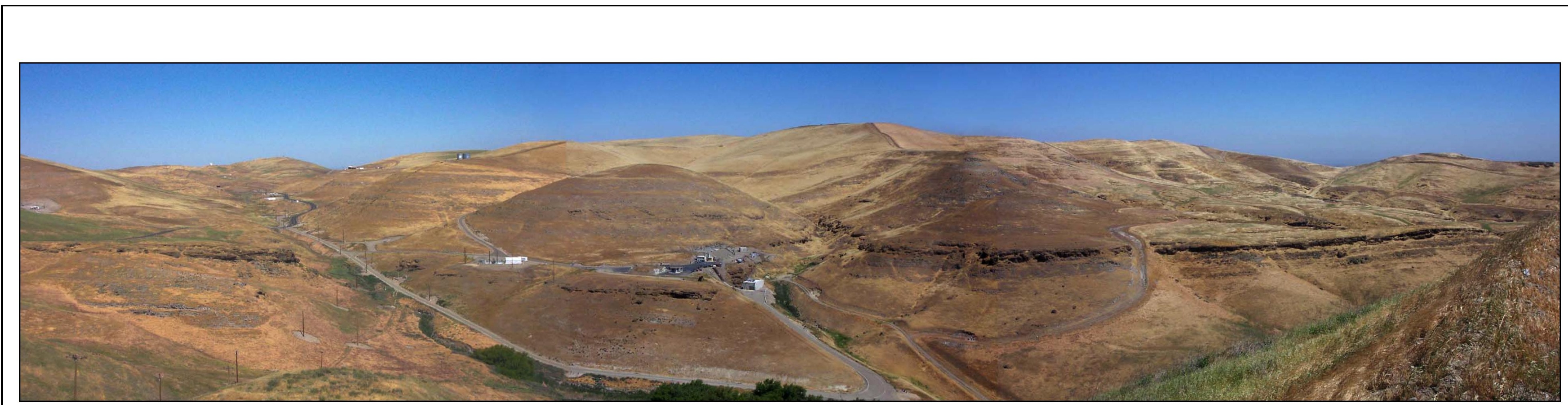

Photographic panorama taken April 2004 by Vic Madrid. View is to the north.

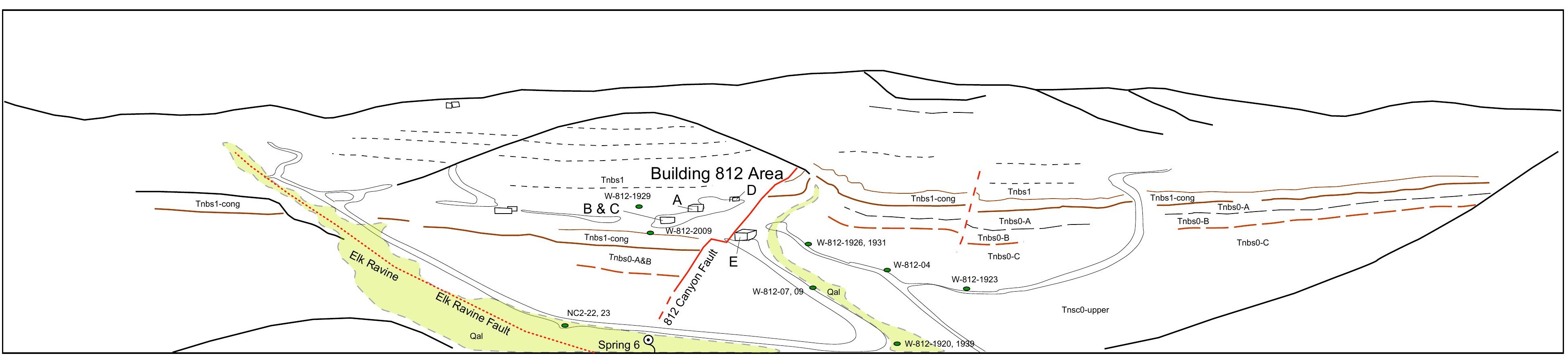

The 812 Canyon Fault separates the Building 812 area into two major fault blocks. Apparent offset is left lateral and down to the west. Spring 6 occurs at the intersection of the fault with Elk Ravine. See report for explanation of stratigraphy. 


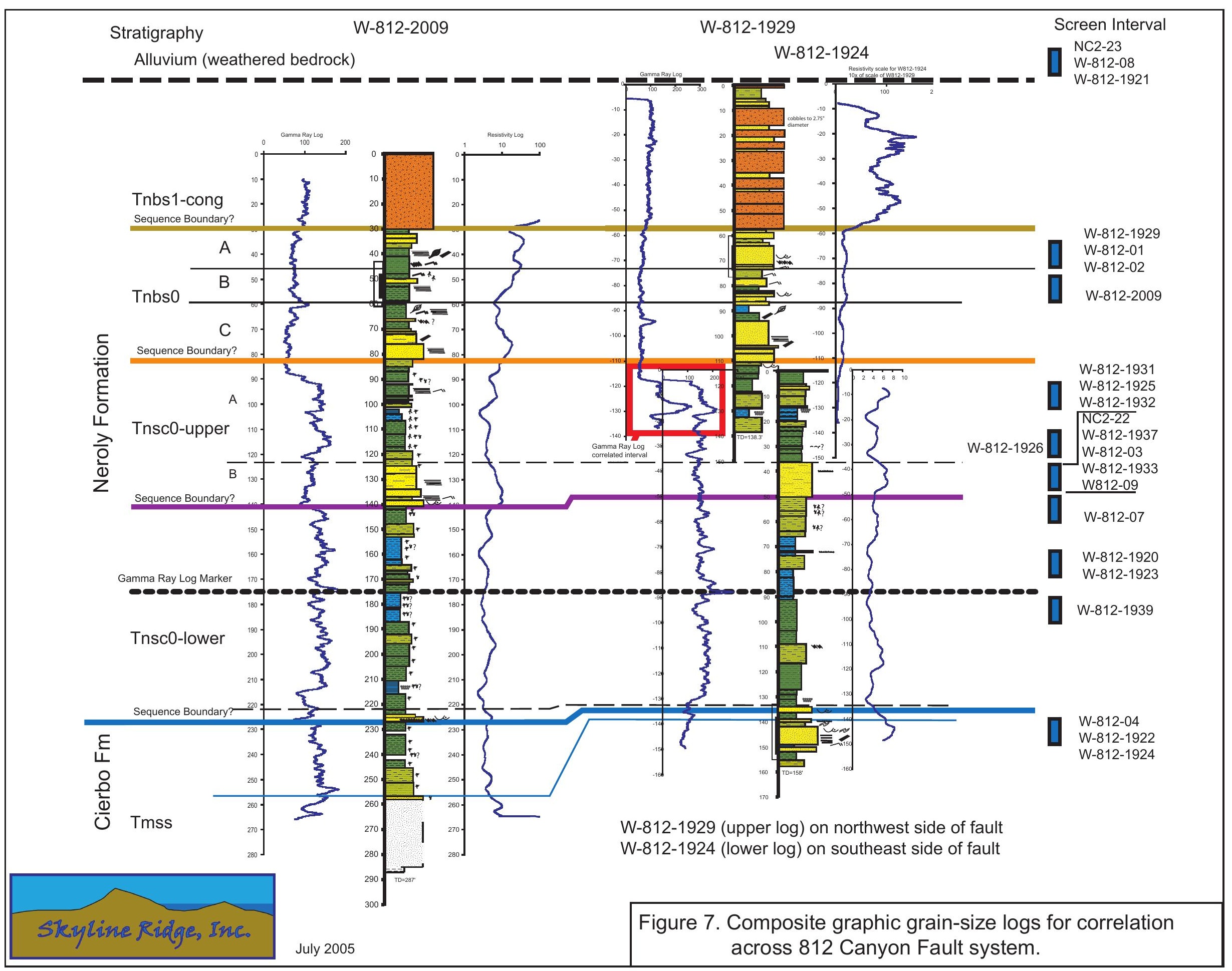




\section{Appendix A}

The following appendix contains the graphic grain-size logs constructed from the drilling geologists' core descriptions. Graphic grain-size logs for W-812-01, W-812-1924, W-812-1929, and W-812-2009 are presented in the body of the report (see Figures 2, 3, and 7). The explanation for the graphic grain-size logs is presented on Figure 3. 

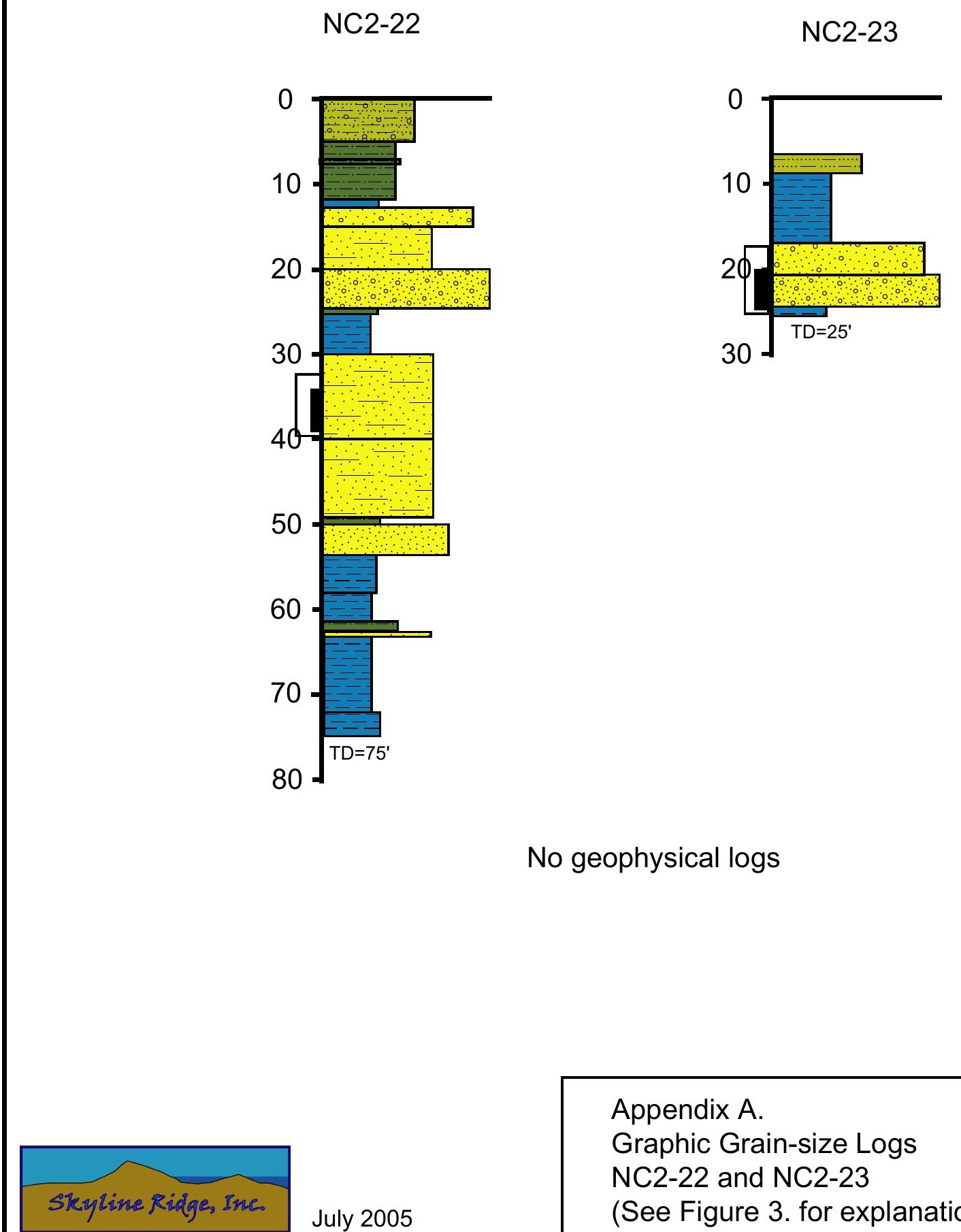

Appendix A.

Graphic Grain-size Logs

NC2-22 and NC2-23

(See Figure 3. for explanation) 


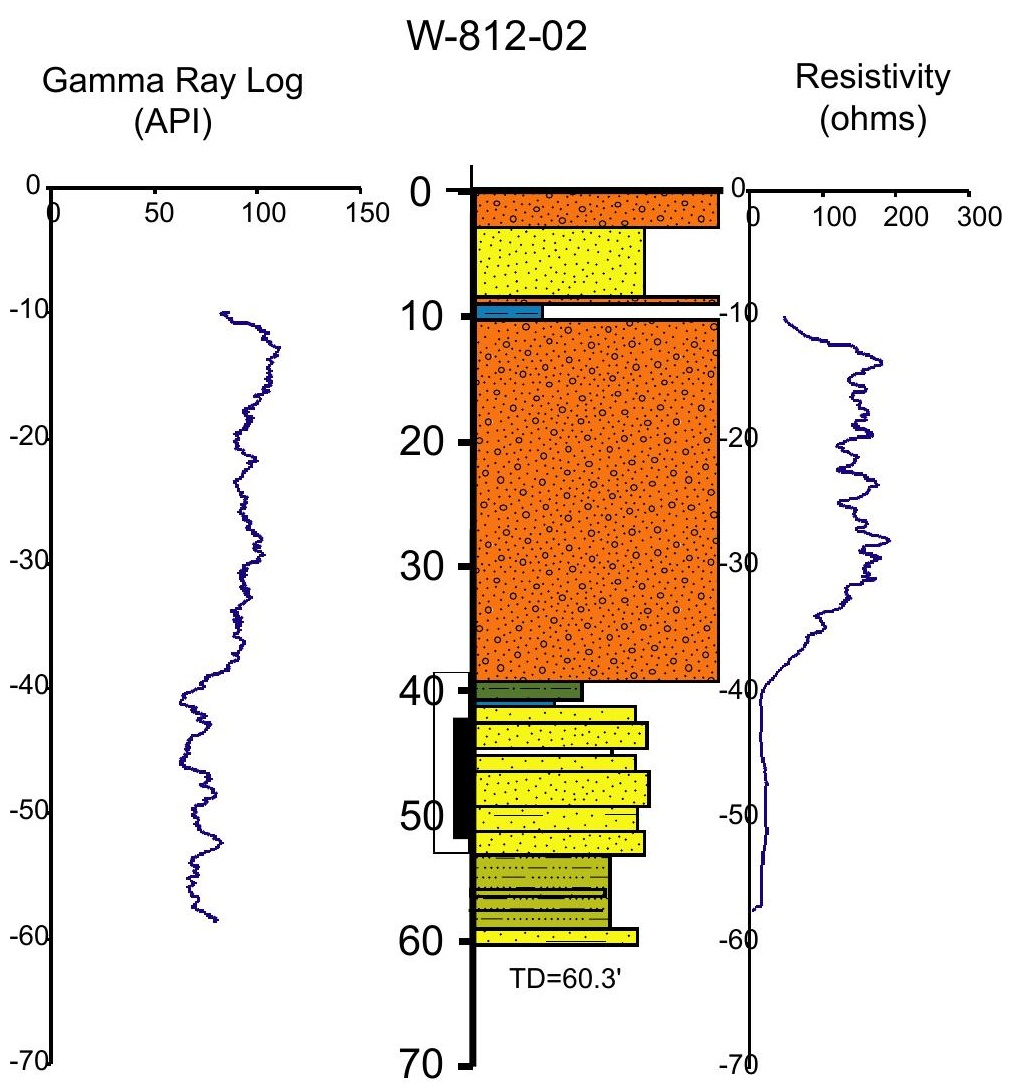

Appendix A.

Graphic Grain-size Log

W-812-02 


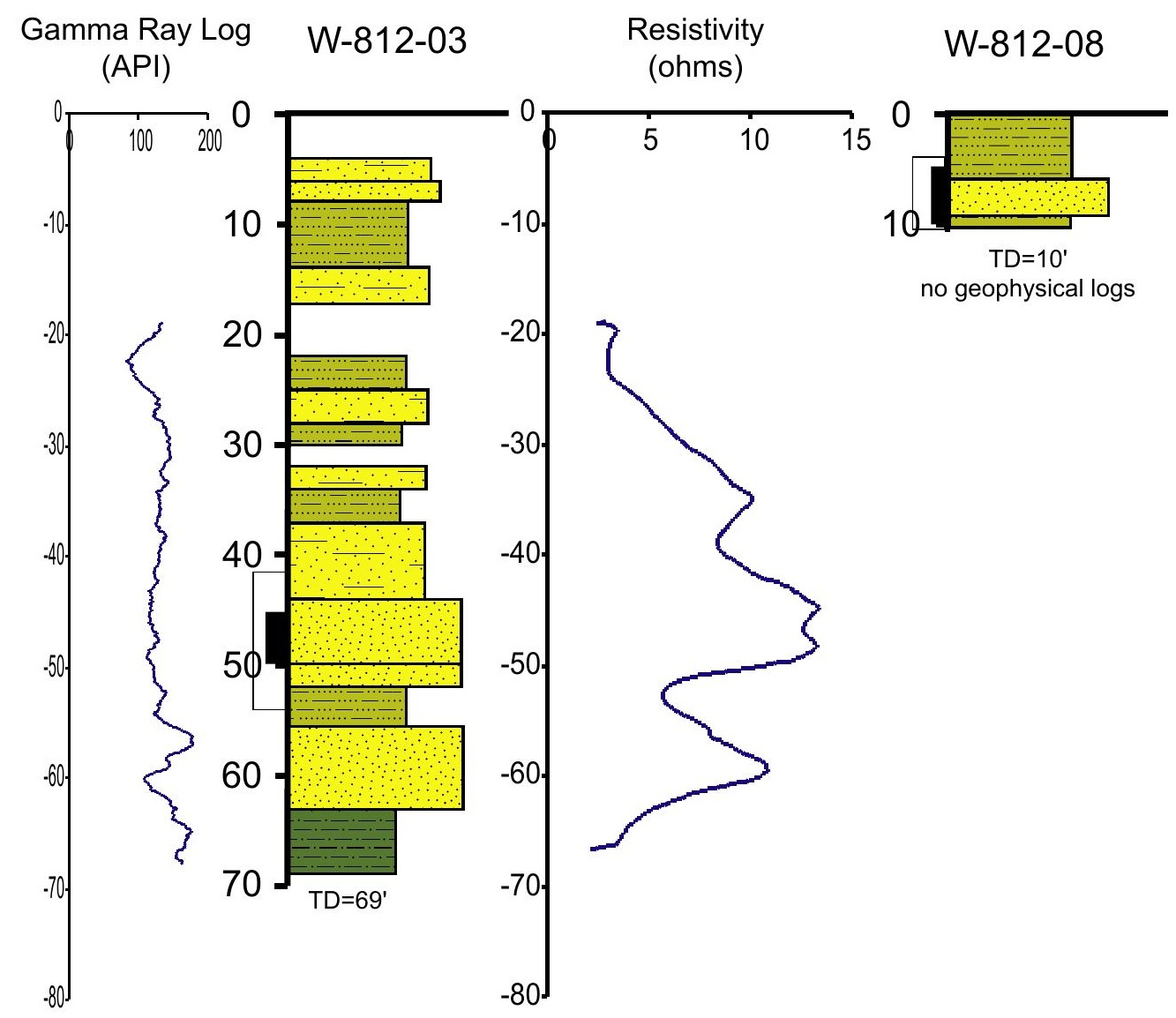

Appendix A.

Graphic Grain-size Logs

W-812-03 and W-812-08 


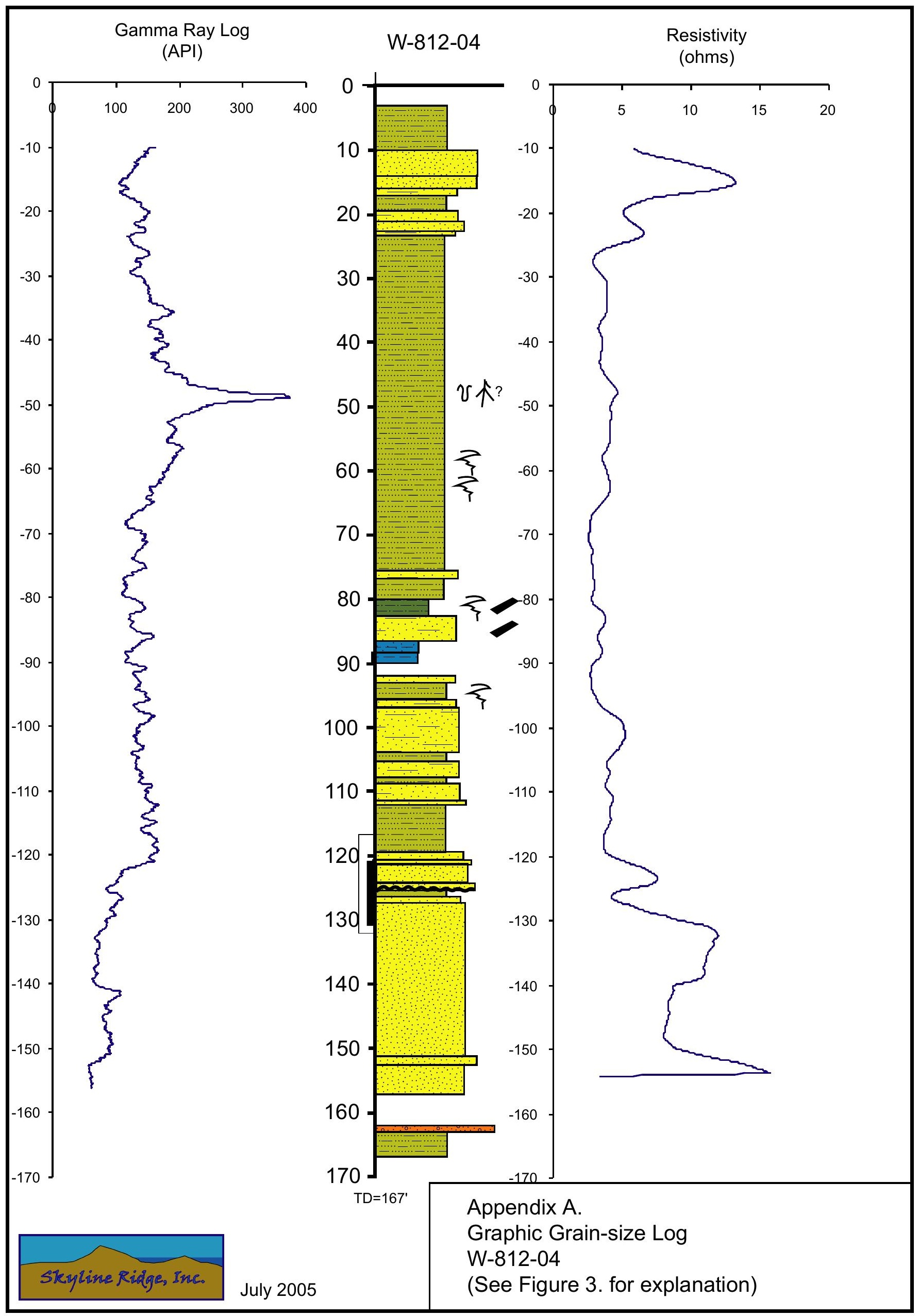




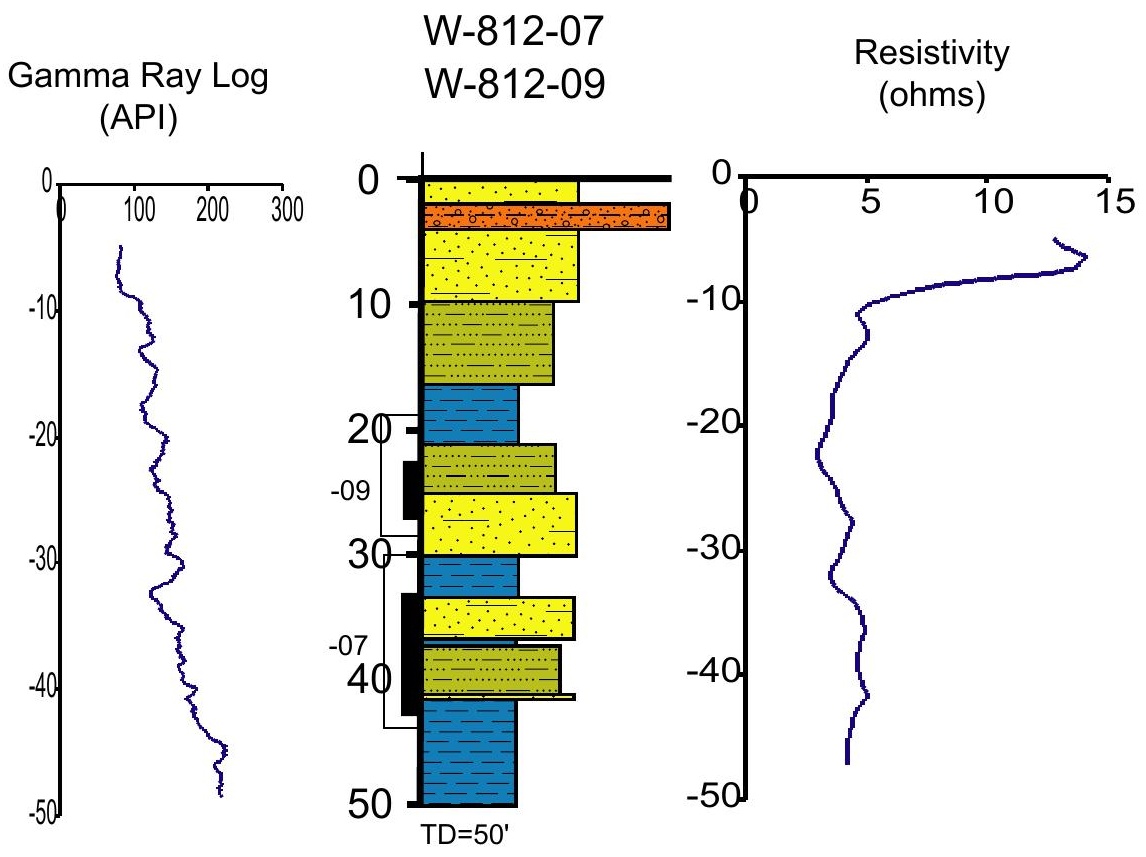

Appendix A.

Graphic Grain-size Logs

W-812-07 and 09 (See Figure 3. for explanation) 


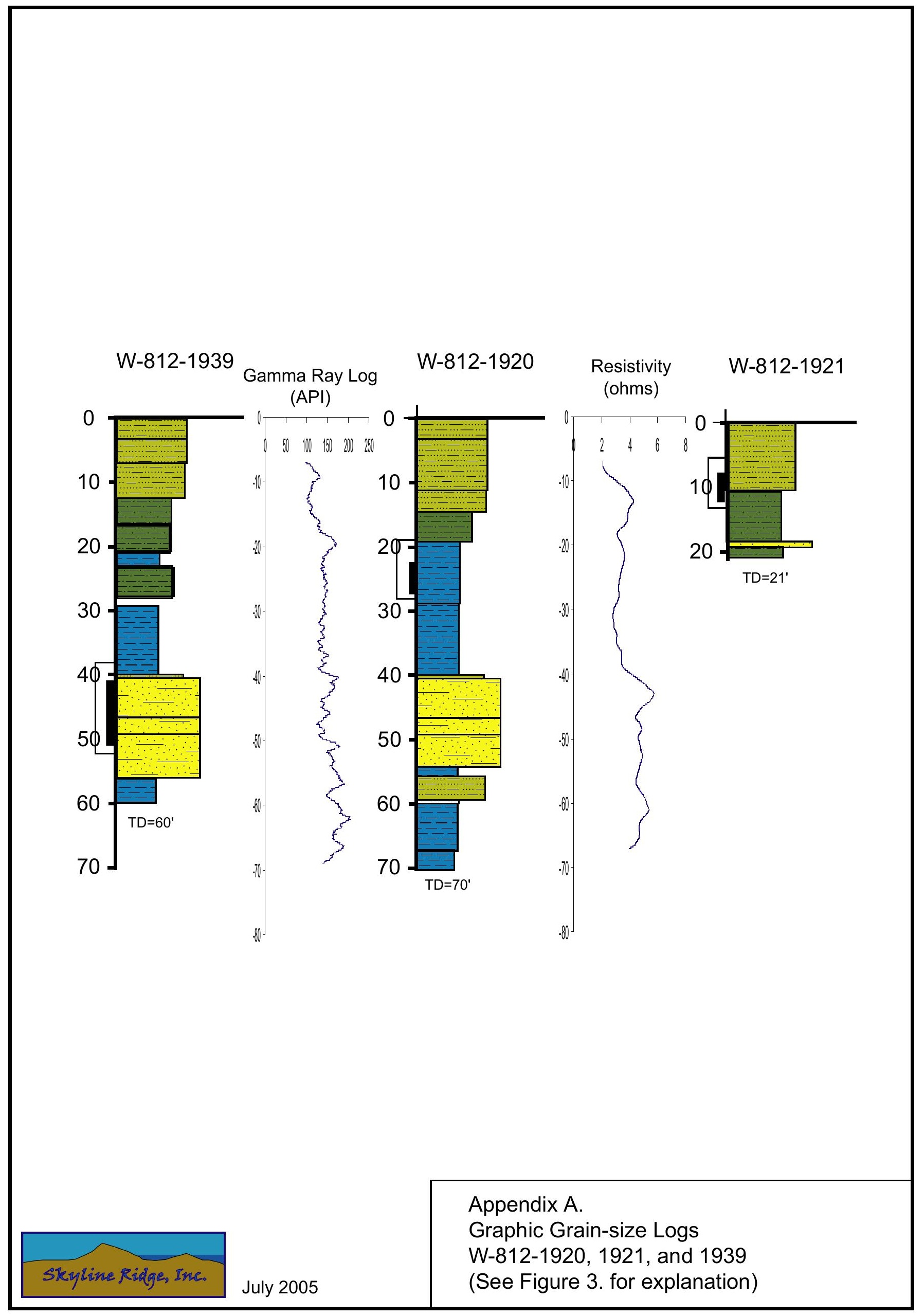




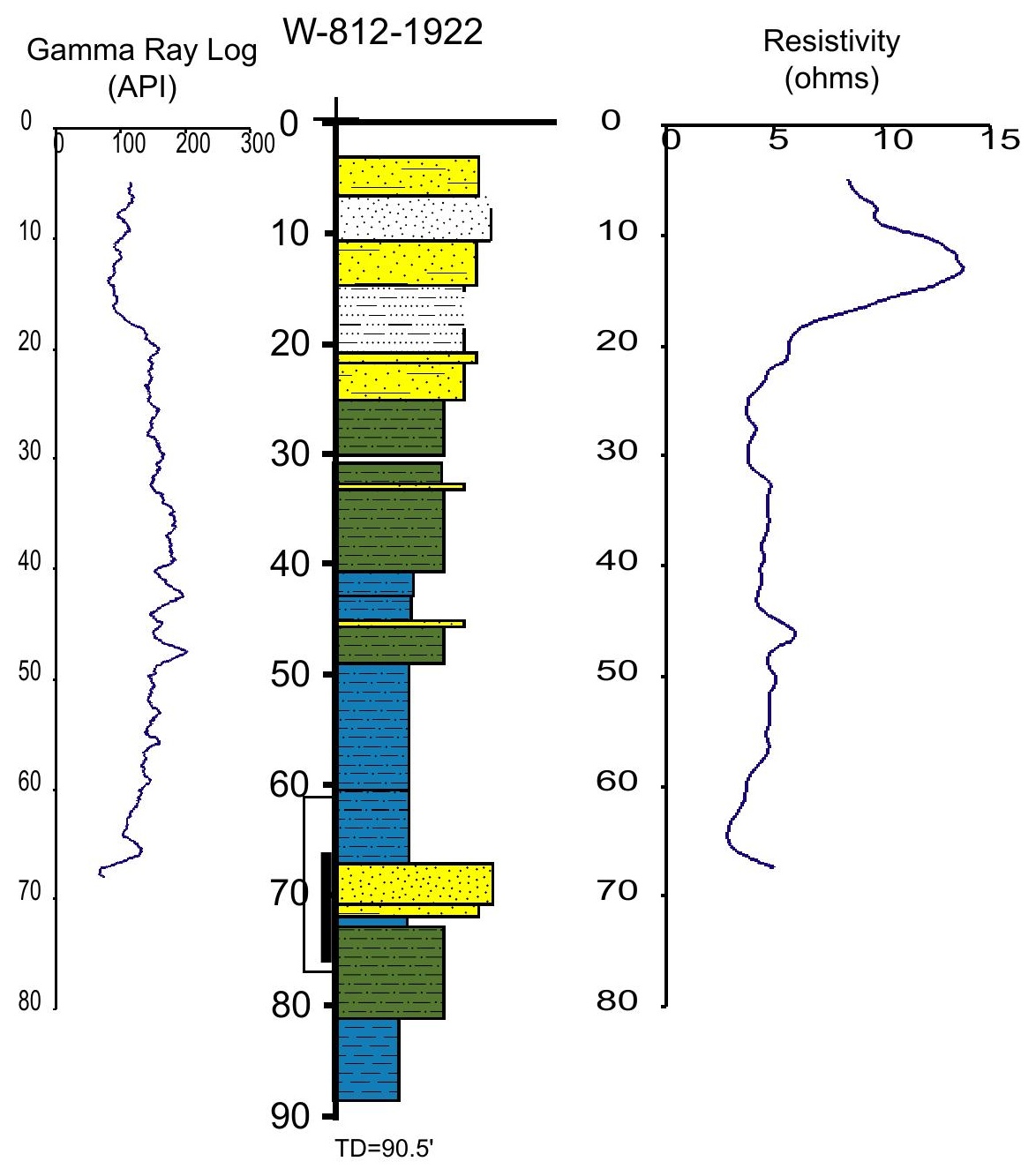

Appendix A.

Graphic Grain-size Log

W-812-1922

(See Figure 3. for explanation) 

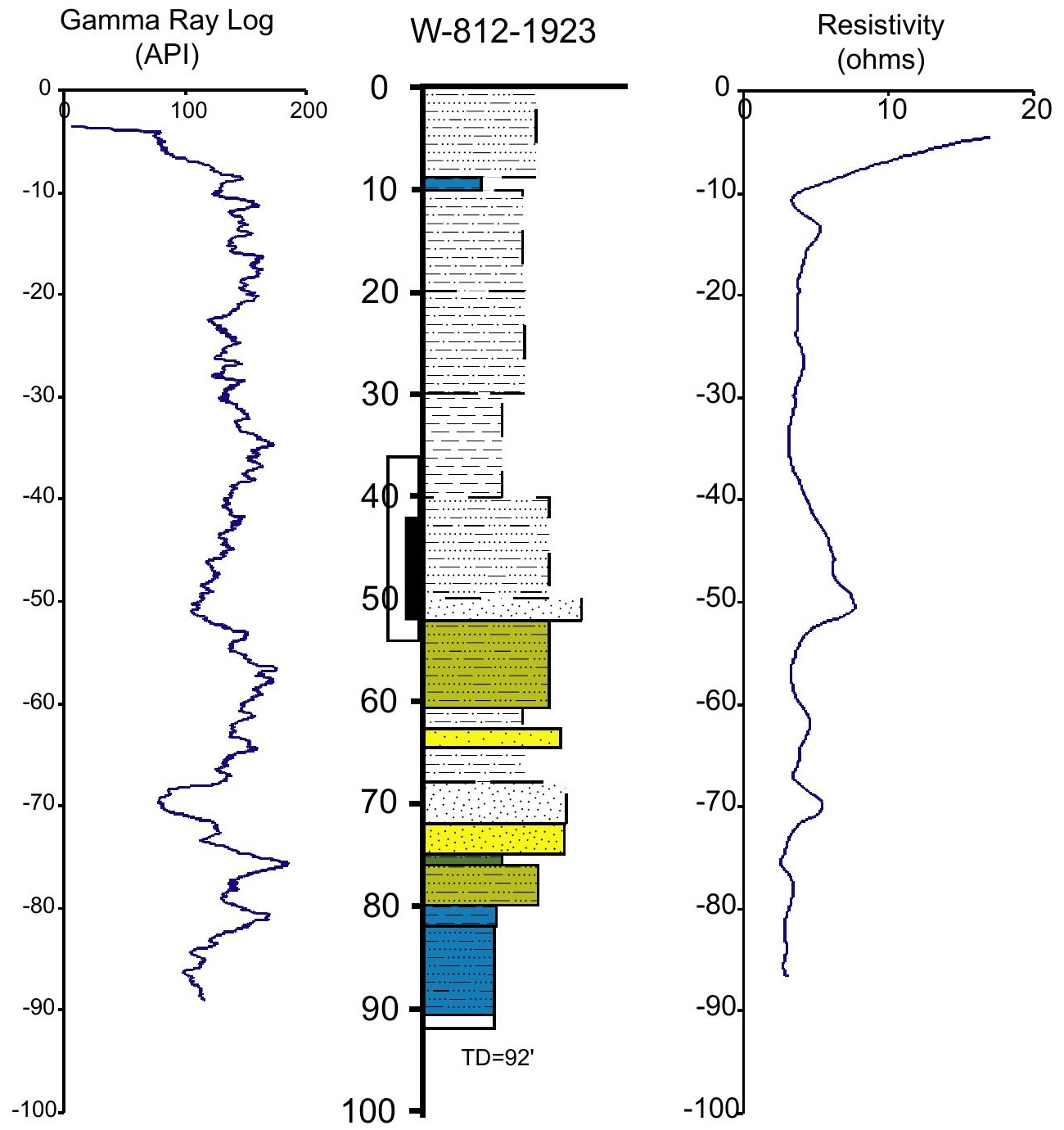

Appendix A.

Graphic Grain-size Logs

W-812-1923

(See Figure 3. for explanation) 


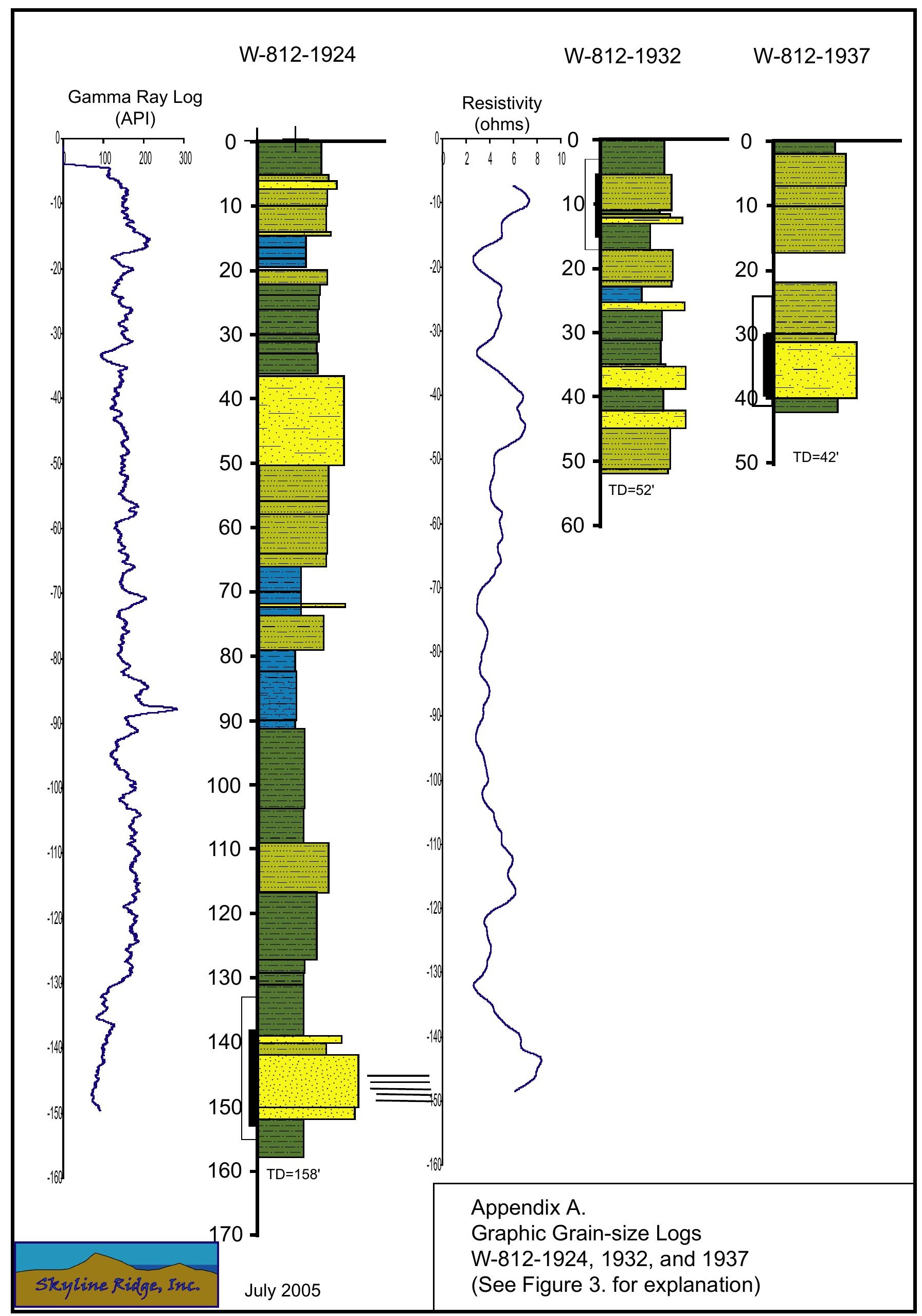




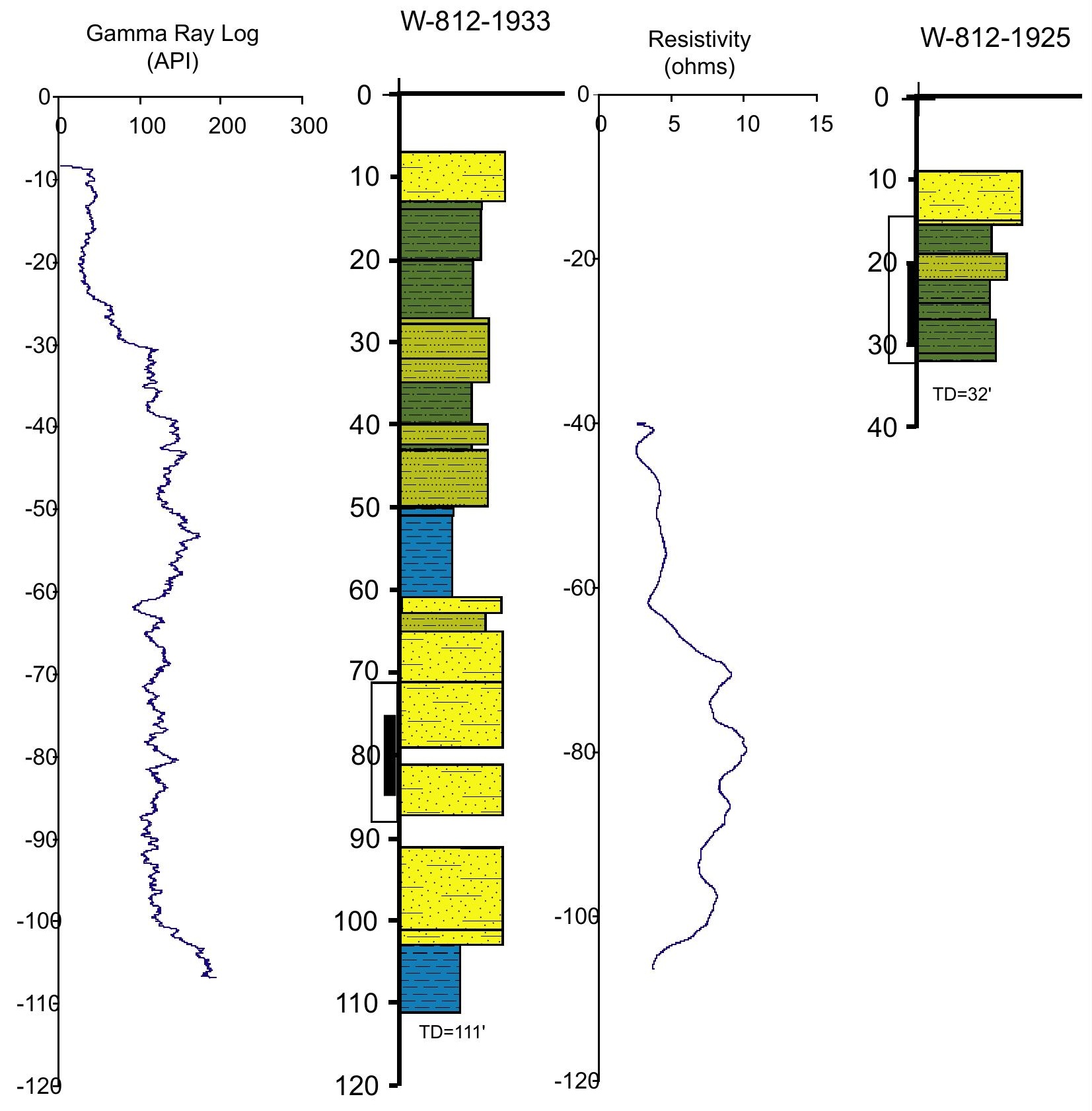

Appendix A.

Graphic Grain-size Logs

W-812-1925 and 1933

July 2005

(See Figure 3. for explanation) 


\section{Appendix B}

The following appendix contains the table of stratigraphic surface picks from each well. 


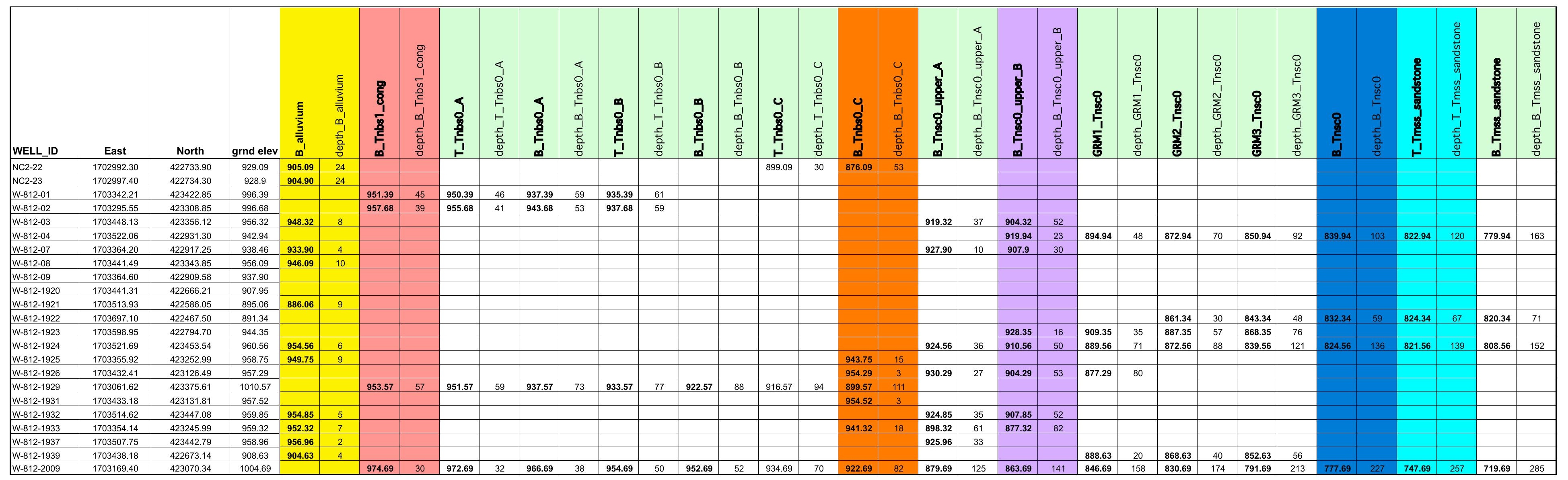

